\title{
Prosopis juliflora invasion and environmental factors on density of soil seed bank in Afar Region, Northeast Ethiopia
}

\author{
Wakshum Shiferaw ${ }^{1 *}$, Tamrat Bekele ${ }^{2}$, Sebsebe Demissew ${ }^{2}$ and Ermias Aynekulu ${ }^{3}$
}

\begin{abstract}
The aims of the study were to analyze (1) the effects of Prosopis juliflora (Prosopis) on the spatial distribution and soil seed banks (SSB) diversity and density, (2) the effects of environmental factors on SSB diversity and density (number of seeds in the soil per unit area), and (3) the effects of animal fecal droppings on SSB diversity, density, and dispersal. Aboveground vegetation data were collected from different Prosopis-infested habitats from quadrats $(20 \times 20 \mathrm{~m})$ in Prosopis thickets, Prosopis + native species stand, non-invaded woodlands, and open grazing lands. In each Prosopis-infested habitats, soil samples were collected from the litter layer and three successive soil layer, i.e., $0-3 \mathrm{~cm}, 3-6 \mathrm{~cm}$, and $6-9 \mathrm{~cm}$. Seeds from soil samples and animal fecal matter were separated in the green house using the seedling emergence technique. Invasion of Prosopis had significant effects on the soil seed bank diversity. Results revealed that the mean value of the Shannon diversity of non-invaded woodlands was being higher by $19.2 \%, 18.5 \%$, and $11.0 \%$ than Prosopis thickets; Prosopis + native species stand and open grazing lands, respectively. The seed diversity and richness, recovered from 6-9-cm-deep layer were the highest. On the other hand, the density of Prosopis seeds was the highest in the litter layer. About 156 of seeds $/ \mathrm{kg}(92.9 \%)$ of seeds were germinated from cattle fecal matter. However, in a small proportion of seedlings, 12 of seeds $/ \mathrm{kg}(7.1 \%)$ were germinated from shot fecal matter. Thus, as the seeds in the soil were low in the study areas, in situ and ex situ conservation of original plants and reseeding of persistent grass species such as Cynodon dactylon, Cenchrus ciliaris, Chrysopogon plumulosus, and Brachiaria ramosa are recommended.
\end{abstract}

Keywords: Afar, Density, Pastoralists, Prosopis juliflora, Rangeland, Soil seed bank

\section{Introduction}

The changeover from seed to plant is a fundamental scheme shaping plant community structure and dynamics (Espinosa et al. 2013). However, in the long run, human-impacted landscapes (Zobel et al. 2007) form a variety of different patterns both in the soil and standing vegetation after disturbances and colonization by aggressive invasive species (Madawala et al. 2016). Soil seed bank (SB) refers to a viable seed which is present in the soil or associated with litter/hummus (Zhang et al., 2017). It represents the potential for the maintenance of

\footnotetext{
* Correspondence: waaqsh@yahoo.com

${ }^{1}$ Arba Minch University, College of Agricultural Sciences, Natural Resources

Management, Arba Minch, Ethiopia

Full list of author information is available at the end of the article
}

plant communities of the past through the improvement of future plant communities in the surrounding area $(\mathrm{Li}$ et al. 2017). SBB are significant as a component of regeneration for succession in ecosystems following disturbances. Thus, buried viable seeds germinate to vegetate disturbed and exposed soil surfaces (Tiebel et al. 2018). The formation of SB is a strategy developed by plants to prevent germination and become viable under unfavorable soil and climate conditions (Saatkamp et al. 2014; Shiferaw et al. 2018b). Thus, analyzing seed bank composition and density is especially important when communities have been invaded by exotic species and must be managed to promote the desired species (Robert and Edith, 2008).

(c) The Author(s). 2019 Open Access This article is distributed under the terms of the Creative Commons Attribution 4.0 International License (http://creativecommons.org/licenses/by/4.0/), which permits unrestricted use, distribution, and reproduction in any medium, provided you give appropriate credit to the original author(s) and the source, provide a link to the Creative Commons license, and indicate if changes were made. The Creative Commons Public Domain Dedication waiver (http://creativecommons.org/publicdomain/zero/1.0/) applies to the data made available in this article, unless otherwise stated. 
Invasive species are introduced either purposely or through natural dispersal mechanisms and are the second threat of global biodiversity loss next to land use changes (Miranda et al. 2011). Prosopis is one of the invasive plant species indigenous to South America, the Caribbean, and Central America (Pasiecznik et al. 2001). Prosopis has been introduced intentionally to Ethiopia particularly in the Afar Region in the late 1970s and 1980s (Berhanu and Tesfaye 2006; Abebe 2012; Haji and Mohammed 2013; Ayanu et al. 2015). Although Prosopis is being used as fuelwood, shade, and dry season fodder for the rural population, the threat posed by it in terms of invasion of fertile agricultural lands, prime grazing lands, and loss of biodiversity are becoming enormous (FAO 2006). In lowlands of Ethiopia, rangelands are subjected to different human and natural impacts. These facilitated for encroaching of undesirable herbaceous weeds and woody plants in rangelands that have become a threat to pastoral production systems (Dalle et al. 2006).

Among the woody encroachers, Prosopis is proving the most invasive species to arid and semi-arid areas in the east and northeast Ethiopia particularly in the Afar Region (Shiferaw et al. 2004; Abebe 2012; Shiferaw et al. 2018a). Land use/cover changes, competitive ecological advantages, and climate change are key factors that are causing the probability of invasion of Prosopis (Pasiecznik et al. 2001; Shiferaw et al. 2018a). When an invasive species becomes firmly established, its control can be difficult and eradication is usually impossible. Moreover, its impact on biodiversity and ecosystem processes can be very serious (Shiferaw et al. 2004).

While comparing the above ground vegetation, investigations on the SSB were undervalued by many researchers all over the world. The reason might be the difficulties in the isolation of viable seeds from the soil samples (Abella et al. 2013). However, SSB is an important component of ecosystem elasticity and represents a stock of regeneration potential in many plant collections. Understanding the diversity and density level of SSB is important for designing conservation and restoration programs in degraded ecosystems particularly in the arid ecosystems. Buried seed populations are therefore considered as essential constituents of plant communities since they help in reclaiming plant communities after disturbances (Song et al. 2017).

Invasive species exert their effect not only on aboveground diversity but also on belowground diversity (Mack and D'Antonio 2003). Knowing seed bank composition and density is imperative when communities have been invaded by exotic species and have to be managed to promote desirable native species (Cox and Allen 2007). Human disturbance would generate significant negative effects on the soil seed bank in arid regions in a semi-arid climate, but SSB in land use types with light/ moderate disturbance are more adapted to vegetation restoration compared with land use types with severe disturbance in a semi-arid region ( $\mathrm{Li}$ et al. 2017). According to Li et al. (2011), the size of the SSB appears to be affected by sampling time, altitude, slope, and soil depth. The possibility of vegetation restoration using the SSB is basically dependent on its seed density and species composition (Duncan et al. 2009; Gonzalez and Ghermandi 2012).

On the other hand, seed dispersal is very important for species diversity, composition, and density. For instance, results showed that both livestock and wildlife species played a critical role in the dispersal of Prosopis and other native species (Mworia et al. 2011). However, in this study, due to financial limitations, we did not evaluate the composition and status of fecal matter of wildlife on seed dispersal.

So far SSB studies in the Afar region have been investigated by few researchers such as Shiferaw et al. (2004) in Middle Awash Rift Valley area, Kebede (2009) at Allideghi Wildlife Reserve, Dessalegn (2010), and Ilukor et al. (2016) in Gewane, Awash Fentale, and Amibara districts.

SSBs are important and largely undiscovered components of woodland and grassland vegetation dynamics. Moreover, update and quantitative information in relation to the effects of alien invasive woody species particularly Prosopis on SSBs of native species are lacking. Changes in the aboveground plants after invasion are well documented than the issue of the changes of SSB after invasions. On the other hand, the factors that modify the invasion effects of Prosopis along with other force variations such as physiographic and anthropogenic factors co-occurrence are unknown.

Therefore, the present study aims to analyze the horizontal and vertical distribution of the SSB of woodlands and grasslands by attempting to answer the following questions: (1) what are the spatial variations in Prosopis in comparison with other native species in SSB? (2) Does Prosopis invasion modulates plant species composition, diversity, density, and richness in lowlands of the South Afar Region? (3) What is the future potential for sprouting propagule sources for Prosopis? (4) Is there a similarity between SSB and standing vegetation in invaded and non-invaded adjacent habitats in lowlands of South Afar Region? (5) Are environmental factors affecting patterns of SSB composition, diversity, richness, and distribution SB in lowlands of the South Afar Region?

\section{Materials and methods}

\section{Description of the study area}

Four Prosopis invaded kebeles (lowest administrative units) (Dudub, Kebena, Kurkira, and Sedihafeghe) were selected from two districts of Awash Fentale and Amibara districts. Amibara district is located between $741-$ 746 m.a.s.l altitudes and $9^{\circ} 19^{\prime} 43.83^{\prime \prime} \mathrm{N}$ and $40^{\circ} 10^{\prime}$ 
51.6" E longitude, whereas Awash Fentale is located between 700-1000 m.a.s.l altitudes and 9 $10^{\prime} 00^{\prime \prime} \mathrm{N}$ latitude and $40^{\circ} 03^{\prime} 33^{\prime \prime} \mathrm{E}$ (Fig. 1).

The mean annual minimum temperature for the district was $16.7^{\circ} \mathrm{C}$. Meanwhile, the mean annual maximum temperature for the district is $37.8^{\circ} \mathrm{C}$ (Fig. 2a). On the other hand, the mean annual temperature of Amibara district is $26.8^{\circ} \mathrm{C}$. The recorded mean annual minimum temperature for the district was $13.8^{\circ} \mathrm{C}$. On the other hand, the mean annual maximum temperature for the districts is $38.2^{\circ} \mathrm{C}$ (Fig. 2b). The study areas are located within lowland agro-ecological zones of Ethiopia. The annual precipitation of Awash Fentale and Amibara districts was $490 \mathrm{~mm}$ and $416 \mathrm{~mm}$ respectively (Fig. $2 \mathrm{a}$ and b).

The study areas are located within lowland agroecological zones of Ethiopia and situated within the Great Rift Valley. The annual precipitation of Awash Fentale and Amibara districts was $490 \mathrm{~mm}$ and $416 \mathrm{~mm}$ respectively (Fig. $2 \mathrm{a}$ and $\mathrm{b}$ ).

The geology of the Afar floristic region is mainly Quaternary and eolian formations (Friis et al. 2010). There are alluvial and colluvial deposits on the foot escarpments and Afar plains. Quite recent, lava is found in the floristic region. The texture of the soils is usually sandy, originating from Jurassic and Cretaceous limestone and other sedimentary rocks.

According to FAO soil classification and ISRIC-world soil information, the soil of the Afar floristic region is lithic and Eutric fluvisols, and Eutric Fluvisols (Friis et al. 2010). Acacia-Commiphora woodland and bushland are among the vegetation types in Ethiopia which characterizing the floristic region (Friis et al. 2010). The population of Amibara and Awash Fentale are 83, 851, and 40,901 respectively (CSA 2013). Ninety percent of Afar people are pastoralists, while another $10 \%$ are considered agro-pastoralist (Wakie et al. 2014).

\section{Sampling design}

\section{Sample site selection}

During a preliminary reconnaissance survey, Prosopis-invaded sites were selected. The sites were selected based on the severity of the threats by Prosopis. The study sites were stratified into approximately homogeneous units based on the following parameters: invasion levels (habitats) of Prosopis, age of the species, land use land cover, and physiography (slope, aspect, and altitude) of the area.

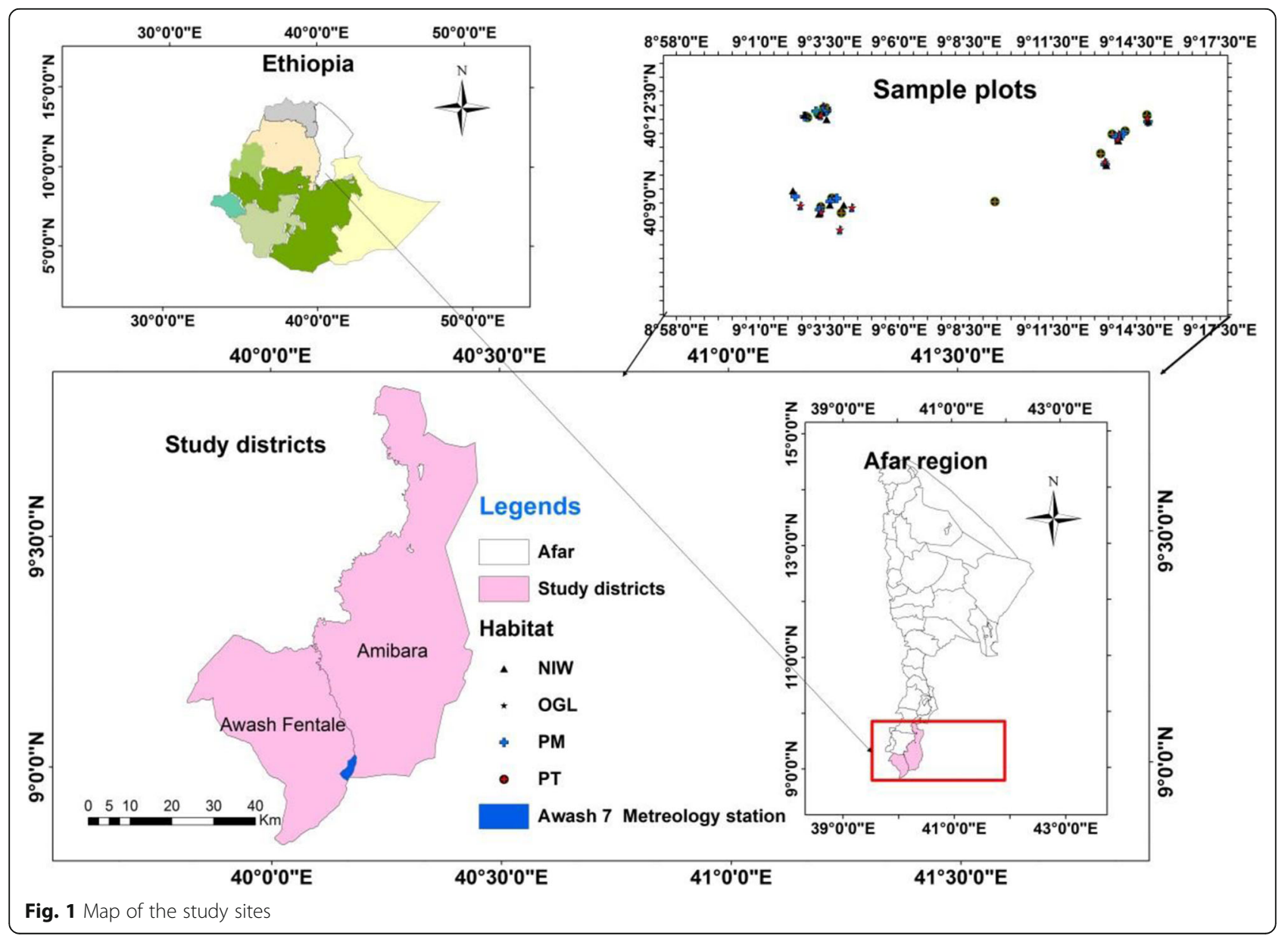




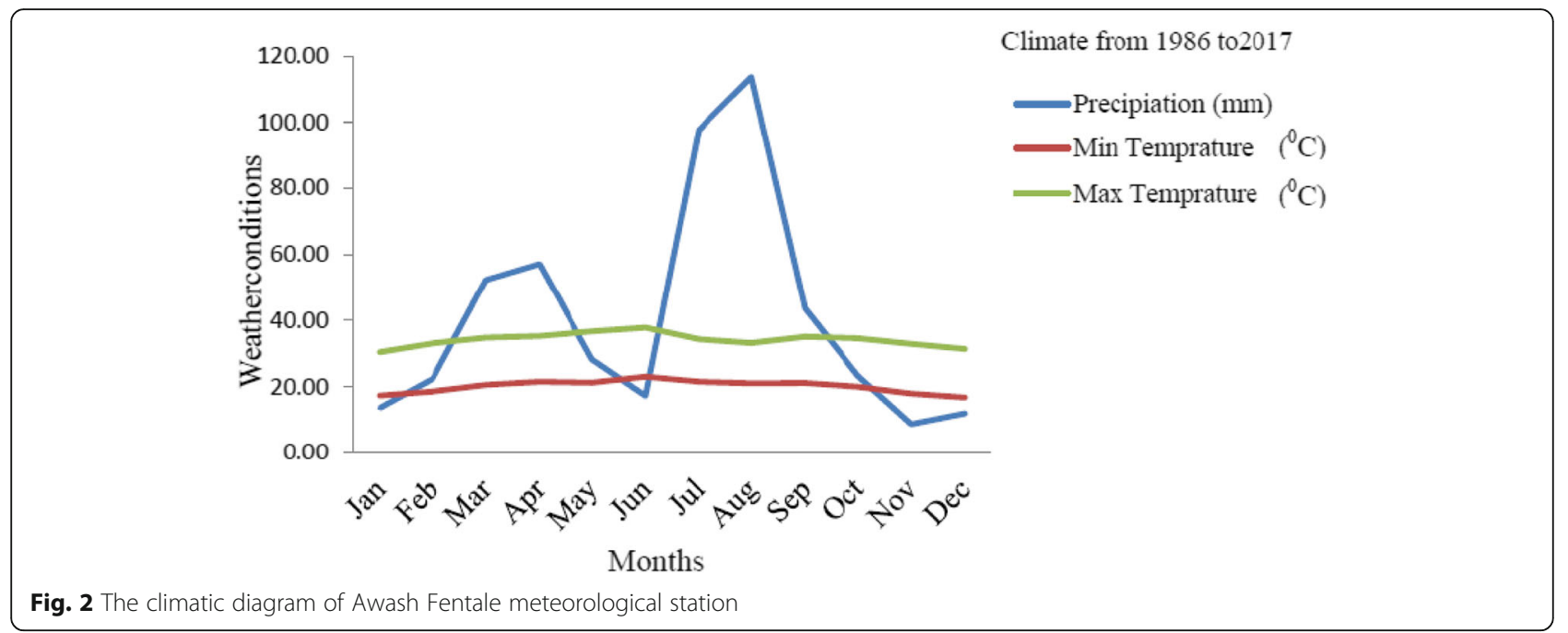

\section{Sample plot layout}

Using the preferential sampling method, quadrats were laid at different infestation levels (habitats) to collect vegetation and other environmental variables (Kent and Coker, 1992). Sixteen collections were sampled in each study area. Thus, vegetation data were collected from (1) Prosopis thicket (PT) which contained $25-100 \%$ of Prosopis, (2) mixed (Prosopis + native woody species) $(\mathrm{PM})<25 \%$ were Prosopis individual stems with native species, (3) non-invaded woodland (NIWL), and (4) open grazing land (OGL) as non-invaded habitats without Prosopis. Each habitat type was categorized according to the composition of dominant Prosopis species as modified by Gairola et al. (2012) and Muturi et al. (2013). Aboveground vegetation data were collected from different Prosopis infestation levels using quadrat sizes of $20 \mathrm{~m} \times 20 \mathrm{~m}\left(400 \mathrm{~m}^{2}\right)$ for PT, PM, and NIW and OGLs. Soil samples for SSB were collected in May 2018.

\section{Data collection}

Soil samples for seed bank analysis were collected using soil auger holding about $196.25 \mathrm{~cm}^{3}$ of soil. A total of 256 soil samples from 64 plots and fresh and dried drops of animal fecal matter were collected for analysis.

SSB soil samples were collected from the litter layer, 0-3-cm, 3-6-cm, and 6-9-cm depth layers from inside plots of $15 \mathrm{~cm} \times 15 \mathrm{~cm}$ area. These sampling plots were set within the larger sampling plot of $400 \mathrm{~m}^{2}$ used for the vegetation sampling. Soil samples were carefully removed from five locations, one in the center and four at each corners of the main plot in each of the habitat types using a sharp knife (Shiferaw et al. 2004). Then, about $1 \mathrm{~kg}$ of composite and representative soil sample for each layer was put in plastic bags and labeled (Sileshi and Abraha 2014).
Sampling was completed within a week to avoid differences between habitats, and any bias in seed availability and composition (Lopez-Toledo and Martínez-Ramos 2011). To investigate the role of animals in the dispersal of seeds for Prosopis and other native species, fecal matter of camels, shoats, goats and sheep, and oxen were collected from their ranches and corrals.

\section{Seed germination and identification}

The number of viable seeds in the soil samples and seed dispersal through droppings of animals was estimated by the seedling emergence technique under conditions favorable for germination (Dalling et al. 1995; LopezToledo and Martínez-Ramos 2011). In the greenhouse, the soil from each sample was prepared and about half a kilogram of soil was placed in plastic trays in the greenhouse at the Central Ethiopia Environment, Forestry and Climate Change Research Center, Addis Ababa, following Dalling et al. (1995).

To prevent possible contamination of the soils with non-experimental seeds, trays were placed in a shade house established in an open site $(<80 \%$ full sunlight) and covered by a layer of white plastic mesh $(<0.5-\mathrm{mm}$ aperture) and transparent nylon sheet (Lopez-Toledo and Martínez-Ramos 2011). Temperatures fluctuated between a minimum of $13^{\circ} \mathrm{C}$ and a maximum of $32^{\circ} \mathrm{C}$ (Reubens et al. 2007). The trays were well watered in a week to keep the soil moist (Lopez-Toledo and Martínez-Ramos 2011). The soil in each tray was watered to saturation every week to induce germination. Seedlings were identified and counted weekly until emergence ceased. Seedling emergences were recorded at least for 6 months (Reubens et al. 2007; Lopez-Toledo and Martínez-Ramos 2011).

Specimens were transplanted on to other pots after seedlings were identified by accession numbers and local 
names, and then, they were removed to minimize confusion with newly emerging plants and possible density effects on further germination following Shiferaw et al. (2004). Each specimen was identified in the National Herbarium of Ethiopia, Addis Ababa University, and using the published Flora of Ethiopia and Eritrea (volumes 1-8).

\section{Physiographic and anthropogenic variables}

Anthropogenic and physiographical gradient variables such as grazing intensities, disturbances, human impacts, altitude, geographical coordinates, slope, and aspects were recorded for each plot. Accordingly, aspect was coded according to Woldu et al. (1989). Grazing intensity was estimated based on visual observation of different symptoms of livestock effects such as animal fecal matters and herbage cuttings following scales designed by Tekle et al. (1997) and Zerihun Woldu and Backeus (1991). The status of human impacts at each plot was estimated using Hadera (2000).

Data analyses and presentation The data analysis of SSB was organized by arranging and recording the data on the Excel datasheet. SSB density, Shannon diversity $\left(H^{\prime}\right)$, vertical distribution, and composition were analyzed using diversity indices to examine species seed dispersal and relate with aboveground flora in different Prosopis-infested habitats and in fecal animal droppings.

The species richness $(R)$ and evenness $\left(E^{\prime}\right)$ of soil seed bank composition in each soil profile were analyzed following the methodology used by Tesfaye et al. (2004) and Perera (2005). Sorensen's coefficient of similarity was used to analyze the similarity between SB compositions among Prosopis-infested habitats. The similarity between the species composition of the SB and that of the vegetation were also calculated by the Sorensen index (Magurran 1988).

$$
\begin{aligned}
& H \ddot{\boldsymbol{E}}=-\Sigma i\left(\left(\frac{\mathrm{ni}}{\mathrm{N}}\right) \ln \left(\frac{\mathrm{ni}}{\mathrm{N}}\right)\right) \\
& E^{\prime}=\frac{H}{H \max }=\frac{H}{\operatorname{lns}}
\end{aligned}
$$

Floristic diversity was assessed using Shannon's diversity index $\left(H^{\prime}\right)$ based on a natural logarithm that gives equal weight to rare and abundant species. It was assumed that the higher the value of $H^{\prime}$, the greater the floristic diversity; $H^{\prime}$ was computed using the Shannon Weaver index (Shannon and Weaver 1949). $E^{\prime}$ is normal between 0 and 1 , and with 1 representing a situation in which all species are equally abundant.

$$
\mathrm{Sj}=\frac{2 a}{(2 \mathrm{a}+\mathrm{b}+\mathrm{c})}
$$

where absolute frequency (AF) represents number of sampling units with species presence/total number of sampling units; relative frequency (RF) represents species absolute frequency/sum of all absolute frequencies * 100; absolute density (AD) represents species total number of individuals/total sampled area; relative density (RD) represents species absolute density/sum of all absolute densities * 100; absolute abundance (AAb) represents species total number of individuals/total number of sampling units that contained the species; and relative abundance (RAb) represents species absolute abundance/sum of all absolute abundances * 100

$$
I_{\mathrm{VI}}=R_{F}+R_{D}+R_{A b}
$$

Where Index of Importance Value $\left(I_{V I}\right)=$ Relative Frequency $\left(R_{F}\right)+$ Relative Density $\left(R_{D}\right)+$ Relative Abundance $\left(R_{A b}\right)$.

Sorensen similarity index was used to determine the pattern of species turnover among the habitats to evaluate the similarity among habitat types in woodland vegetation. It is determined using Sorensen similarity index (Sorensen 1948). Species data were organized in spreadsheets using Microsoft Excel 2010. Importance value index for each species computation was performed using Muller-Dombis and Ellenberg (1974).

CCA ordination was performed to evaluate soil seed bank similarity in terms of the abundance of species among sites and habitats. The length of arrows in CCA indicated that strength of environmental factors with the site, species composition, and diversity of seed banks in the soil. For this procedure, species abundance at each site was used to obtain a similarity matrix using a base R software version 3.5.1 (The R Core Team 2018). Then, \# Program 3.9.2.3(3) for CCA displaying sites constrained by some selected environmental variables was used to analyze data. It showed that quadrats 1-16 were for Dudub, quadrats 17-32 for Kebena site, 33-48 for Kurkurs, and quadrats 49-64 for Sedihafeghe site (Fig. 4). A separate analysis was conducted for each plant seed groups such as seeds of forest pioneer species, seeds of climax tree species, and seeds of invasive pioneer species (Reubens et al. 2007).

The composition and density of seeds in the soil were determined by data obtained from germination. The density of seeds was derived from the total number of seeds recovered from the soil samples. On the other hand, to analyze the depth distribution of seeds in each, the number of seeds recovered in similar layers were combined and converted to provide the density of seeds per square meter at that particular soil depth following the methodology used by Kebede (2009) and Shiferaw et al. (2004). 
Seed diversity in the soil was also analyzed using $\mathrm{R}$ software version 3.5.1 (The R Core Team 2018). All data were statistically analyzed using the one-way analysis of variance (ANOVA). Duncan's multiple range tests were applied to test differences among means of habitats, physiographic, and anthropogenic factors on soil seed patterns. The statistical analysis was performed by using SAS version 9.0 (SAS 2002) and SPSS version 24 (IBM 2016) to compute the number of families and growth forms in each habitat. Then, histograms were drawn using Microsoft Excel Software.

\section{Results}

\section{Invasion effects of Prosopis on soil seed bank} composition and diversity

Nineteen plant species belonging to 11 families were identified in SSBs, while 161 plant species, belonging to 32 families, were identified in the aboveground flora. Although results indicated that several families and plant growth habits were not significantly affected by Prosopisinvaded levels. Numerically, the mean values of habitats revealed variations in the study areas. From the total of 11 families recorded from the SSB, 8 (72.7\%), 7 (63.6\%), $9(81.8 \%)$, and $7(63.6 \%)$ were recorded in PT, PM, NIWL, and OGLs, respectively.

The three top frequent families in the study area were Poaceae, Asteraceae, and Lamiaceae which had contributed 12 (25\%), 8 (16.7\%), and 6 (12.5\%) species in the SSB. Fabaceae and Solanaceae together contributed to $25 \%$ of the total species while the rest of the families contributed to $20.8 \%$. Other families contributed (for instance, Convolvulaceae, Rhamnaceae, and Cyperaceae) to only $2.1 \%$ in PT, PM, and NIWLs (Table 11 in Appendix).

Twenty-nine $(60.4 \%)$ of the germinated seedlings were identified as forbs while $13(27.1 \%), 3(6.3 \%)$, and 3 (6.3\%) were grass, climber, and tree (woody) species, respectively. The number of species collected from the different habitats were 15 (NIWL), 12 (OGL), 11 (PT), and 10 (PM). Graminoid species were most frequent (8.3\%) in NIWL. In the rest of the habitats, graminoid species were equally distributed. A very low proportion of climbers and woody species were identified from all habitat types (Table 1; Table 10 in Appendix).
ANOVA results revealed that invasion of Prosopis had highly significant effects on SSB $H^{\prime}(F=14.36, P<$ $0.0001)$ and $R(F=17.57, P=<0.0001)$. But, habitats did not show significant effect on $E^{\prime}(F=0.12, P=0.95)$. But, no significant variations were observed between PT and PM (Table 2; Figs. 4 and 5).

\section{Spatial distribution of soil seed banks}

With regard to horizontal distribution of SSB, ANOVA results $H^{\prime}(F=13.05, P=0.0002), R(F=21.85, P<0.0001)$, and $E^{\prime}(F=8.4, P=0.004)$. Moreover, sites had also shown significant effects on $H^{\prime}(F=25.8, P<0.0001), R(F=32.2$, $P<0.0001)$, and $E^{\prime}(F=27.5, P<0.0001)$ (Table 10 in Appendix). At Amibara district, $H^{\prime}$ was higher at Awash Fentale district. Moreover, the mean value of $R$ for Amibara district was higher than those of Awash Fentale district, but $E^{\prime}$ of Awash Fentale was higher than Amibara district. On the other hand, $H^{\prime}$ of Kebena site was higher than Dudub, Sedihafeghe, and Kurkura sites, respectively. However, $R$ at Kurkura site was higher than Dudub, Kebena, and Sedihafeghe sites, respectively. Moreover, $E^{\prime}$ of SB in Sedihafeghe site was higher than Dudub, Kebena, and Kurkura sites, respectively (Table 3 ).

\section{Vertical patterns of soil seed bank}

SSB did not show significant variations among soil layers. Numerically, the 6-9-cm soil depth showed higher mean values of $H^{\prime}$ and $R$ than the rest of soil layers. But, about the same $E^{\prime}$ was recorded in both soil layers (Table 4).

In this study, a total of 50,578 seedlings of 19 species per square meter emerged from the SSB and 168 seedlings of 6 species per kilogram emerged from animal fecal matter (Table 12 in Appendix; Table 9). Overall results showed that 34,044 seeds $/ \mathrm{m}^{2}$ was recorded from the litter layer. Out of these $2889 \pm 26.40$ seeds $/ \mathrm{m}^{2}$, $8356 \pm 14.24$, and $5289 \pm 11.35$ seeds $/ \mathrm{m}^{2}$ were recorded in $0-3-\mathrm{cm}$ soil layer, $3-6-\mathrm{cm}$, and $6-9-\mathrm{cm}$ seeds $/ \mathrm{m}^{2}$, respectively (Table 12 in Appendix; Fig. 3). In CCA, the length of the arrow indicated that density and composition of seeds in the soil were highly determined by altitude, disturbance, and grazing intensities. Results also revealed that site (Dudub, Kebena, Kurkura, and Sedihafeghe), altitude, slope, aspect, human impact, grazing

Table 1 Distribution of growth forms in each habitat

\begin{tabular}{|c|c|c|c|c|c|c|c|c|c|c|c|}
\hline & & \multicolumn{10}{|l|}{ Habitat } \\
\hline & & \multicolumn{2}{|l|}{$\overline{\mathrm{PT}}$} & \multicolumn{2}{|l|}{ PM } & \multicolumn{2}{|l|}{ NIWL } & \multicolumn{2}{|l|}{ OGL } & \multicolumn{2}{|l|}{ Total } \\
\hline & & Frequency & $\%$ & Frequency & $\%$ & Frequency & $\%$ & Frequency & $\%$ & Frequency & $\%$ \\
\hline \multirow[t]{4}{*}{ Life form } & Forb & 5.0 & 10.4 & 6.0 & 12.5 & 11.0 & 22.9 & 7.0 & 14.6 & 29.0 & 60.4 \\
\hline & Grass & 3.0 & 6.3 & 4.0 & 8.3 & 3.0 & 6.3 & 3.0 & 6.3 & 13.0 & 27.1 \\
\hline & Climber & 2.0 & 4.2 & 0.0 & 0.0 & 1.0 & 2.1 & 0.0 & 0.0 & 3.0 & 6.3 \\
\hline & Tree & 1.0 & 2.1 & 0.0 & 0.0 & 0.0 & 0.0 & 2.0 & 4.2 & 3.0 & 6.3 \\
\hline Total & & 11.0 & 22.9 & 10.0 & 20.8 & 15.0 & 31.3 & 12.0 & 25.0 & 48.0 & 100.0 \\
\hline
\end{tabular}


Table 2 Effects of Prosopis invasion levels on soil seed bank patterns in South Afar of Ethiopia

\begin{tabular}{llll}
\hline Habitat & $H^{\prime}$ & $R$ & $E^{\prime}$ \\
\hline PT & $1.18 \pm 0.03 c$ & $3.94 \pm 0.15 b c$ & $0.93 \pm 0.01 a$ \\
PM & $1.19 \pm 0.04 c$ & $3.83 \pm 0.013 c$ & $0.94 \pm 0.01 a$ \\
NIWL & $1.46 \pm 0.04 a$ & $5.13 \pm 0.15 a$ & $0.93 \pm 0.01 a$ \\
OGL & $1.30 \pm 0.05 b$ & $4.3 \pm 0.17 b$ & $0.94 \pm 0.01 a$ \\
\hline
\end{tabular}

Notice: $H^{\prime}$ is the Shannon-Wiener index, $R$ is species richness, and $E^{\prime}$ is the

Shannon evenness; the same letters indicate insignificant variations at $P<0.05$

intensity, and disturbance intensity had correlated by $19 \%, 10 \%, 6 \%, 6 \%, 5 \%, 4 \%$, and $5 \%$ in that order with quadrats. For instance, $71 \%$ of soil seed bank patterns were constrained by sites in CCA1, and $65 \%$ in the CCA2, and $13 \%$ in the CCA3 (Table 5, Fig. 4)

Results showed that 13,333 seeds of the species Brachiaria leersioides, 6178 seeds of the species Parthenium hysterophorus, and 5689 seeds of the species Eragrostis aethiopica were recorded from the litter layer. These figures were higher than those obtained for Prosopis $(222$ seeds $\left./ \mathrm{m}^{2}\right)$ and Ziziphus spina-christi $\left(89\right.$ seeds $\left./ \mathrm{m}^{2}\right)$. A total of 44 seeds $/ \mathrm{m}^{2}$ of Solanum incanum, Crotalaria pycnostachya, Trifolium simense, and E. aethiopica each were identified. In addition, 14,178 seeds of $B$. leersioides, 4533 seeds of $P$. hysterophorus, 2667 seeds of $E$. aethiopica, and 1556 seeds of Bidens pilosa were collected per square meter were recorded from the $0-3-\mathrm{cm}$ soil layer. Likewise, 44 seeds $/ \mathrm{m}^{2}$ each for Ipomoea blepharophylla, Fuirena leptostachya, Heliotropium longiflorum, and Coccinia grandis were identified from the same layer (Table 12 in Appendix).

Results show a decrease in density of SSB with depth. Accordingly, a density of 3289 seeds $/ \mathrm{m}^{2}$ of B. leersioides, 2578 seeds $/ \mathrm{m}^{2}$ of $P$. hysterophorus, and 1022 seeds $/ \mathrm{m}^{2}$ of Amaranthus thunbergii species was recovered from soil samples in $3-6-\mathrm{cm}$ soil layer. These values were far higher than 44 of seeds $/ \mathrm{m}^{2}$ for P. crispus, Ipomoea indica, and Cenchrus ciliaris. No Prosopis seedling in the 3-6-cm soil layer. Meanwhile, 2444 and 11,022 of seeds/ $\mathrm{m}^{2}$ were recorded in that order for $B$. leersioides and $P$. hysterophorus in 6-9-cm soil depth. But, 44,133 and 178 of seeds $/ \mathrm{m}^{2}$ were recovered in soil depth of $6-9 \mathrm{~cm}$ for

Table 3 Effects of sites and district on values of soil seed bank patterns

\begin{tabular}{lllll}
\hline & Locations & $H^{\prime}$ & $R$ & $E^{\prime}$ \\
\hline Districts & Awash Fentale & $1.20 \pm 0.03 \mathrm{~b}$ & $3.93 \pm 0.1 \mathrm{~b}$ & $0.94 \pm 0.006 \mathrm{a}$ \\
& Amibara & $1.34 \pm 0.02 \mathrm{a}$ & $4.63 \pm 0.11 \mathrm{a}$ & $0.92 \pm 0.006 \mathrm{~b}$ \\
Sites & Dudub & $1.02 \pm 0.03 \mathrm{~b}$ & $3.2 \pm 0.12 \mathrm{c}$ & $0.95 \pm 0.008 \mathrm{ab}$ \\
& Kebena & $1.38 \pm 0.03 \mathrm{a}$ & $4.65 \pm 0.04 \mathrm{~b}$ & $0.93 \pm 0.009 \mathrm{~b}$ \\
& Kurkura & $1.37 \pm 0.04 \mathrm{a}$ & $5.07 \pm 0.15 \mathrm{a}$ & $0.87 \pm 0.01 \mathrm{c}$ \\
& Sedihafeghe & $1.32 \pm 0.04 \mathrm{a}$ & $4.28 \pm 0.14 \mathrm{~b}$ & $0.96 \pm 0.005 \mathrm{a}$
\end{tabular}

Notice: $H^{\prime}$ is the Shannon-Wiener index, $R$ is species richness, and $E^{\prime}$ is the Shannon evenness; the same letters indicate insignificant variations at $P<0.05$
Table 4 Effects of soil layer on mean values of soil seed bank patterns

\begin{tabular}{llll}
\hline Soil Layer & $H^{\prime}$ & $R$ & $E^{\prime}$ \\
\hline Litter layer & $1.28 \pm 0.03 a$ & $4.29 \pm 0.12 \mathrm{a}$ & $0.93 \pm 0.01 \mathrm{a}$ \\
$0-3 \mathrm{~cm}$ & $1.25 \pm 0.03 \mathrm{a}$ & $4.2 \pm 0.14 \mathrm{a}$ & $0.93 \pm 0.01 \mathrm{a}$ \\
$3-6 \mathrm{~cm}$ & $1.29 \pm 0.05 \mathrm{a}$ & $4.39 \pm 0.21 \mathrm{a}$ & $0.94 \pm 0.01 \mathrm{a}$ \\
$6-9 \mathrm{~cm}$ & $1.32 \pm 0.06 \mathrm{a}$ & $4.44 \pm 0.24 \mathrm{a}$ & $0.94 \pm 0.01 \mathrm{a}$ \\
\hline
\end{tabular}

Notice: $H^{\prime}$ is the Shannon-Wiener index, $R$ is species richness, $E^{\prime}$ is the Shannon evenness; the same letters indicate insignificant variations at $P<0.05$

T. simense, P. lagascae, and B. pilosa, respectively. Moreover, 89 seeds $/ \mathrm{m}^{2}$ each for C. ciliaris and Crotalaria pycnostachya were recovered from soil samples in the 6-9cm soil layer (Table 12 in Appendix).

Concerning ecological availability of seeds in SBs, results revealed the same $I_{\mathrm{VI}}$ patterns with that of the density of species as aforementioned seeds which existed in the upper and subsoils. For instance, higher $I_{\mathrm{VI}}$ values were computed for B. leersioides, E. aethiopica, C. pycnostachya, and P. hysterophorus in both layers, whereas lower $I_{\mathrm{VI}}$ values which were computed for Prosopis, Solanum incanum, T. simense, P. crispus, C. grandis, Fuirena leptostachya, H. longiflorum, C. ciliaris, I. indica, and C. pycnostachya seeds in litter layer and across soil depths (Table 12 in Appendix).

\section{Soil seed bank versus standing vegetation}

Results showed that a much larger number of species occur in the aboveground vegetation than represented in the soil seed bank. The Sorenson similarity coefficient revealed that aboveground vegetation species under Prosopis thickets were similar to belowground flora under the habitats of Prosopis with native species stands, noninvaded woodlands, and open grazing lands, respectively. Meanwhile, species in the aboveground flora under noninvaded woodlands was similar to the belowground flora under open grazing lands and aboveground species under Prosopis with native species stands was similar to soil flora of non-invaded woodlands and open grazing lands (Table 6).

\section{Physiographic factors and soil seed bank diversity}

The physiographic effects on plant species diversity are presented in Tables 10 and 12 in Appendix. Results indicated that both $H^{\prime}(F=9.97, P<0.0001), R(F=3.84, P$ $=0.02)$, and $E^{\prime}(F=14.97, P<0.0001)$ were significantly affected by altitude. On the other hand, $H^{\prime}(F=10.08, P$ $<0.0001), R(F=12.66, P=0.02)$, and $E^{\prime}(F=39.31, P<$ $0.0001)$ were significantly affected by the slope. Moreover, $H^{\prime}(F=23.46, P<0.0001), R(F=38.51, P=0.02)$, and $E^{\prime}(F=17.85, P<0.0001)$ were also significantly affected by aspect. The mean values for altitudinal ranges revealed that $H^{\prime}$ at lower altitude ranges (740-790 m.a.s.l) was higher by $12.4 \%$ than at higher altitudes (> 841 m.a.s.l). 


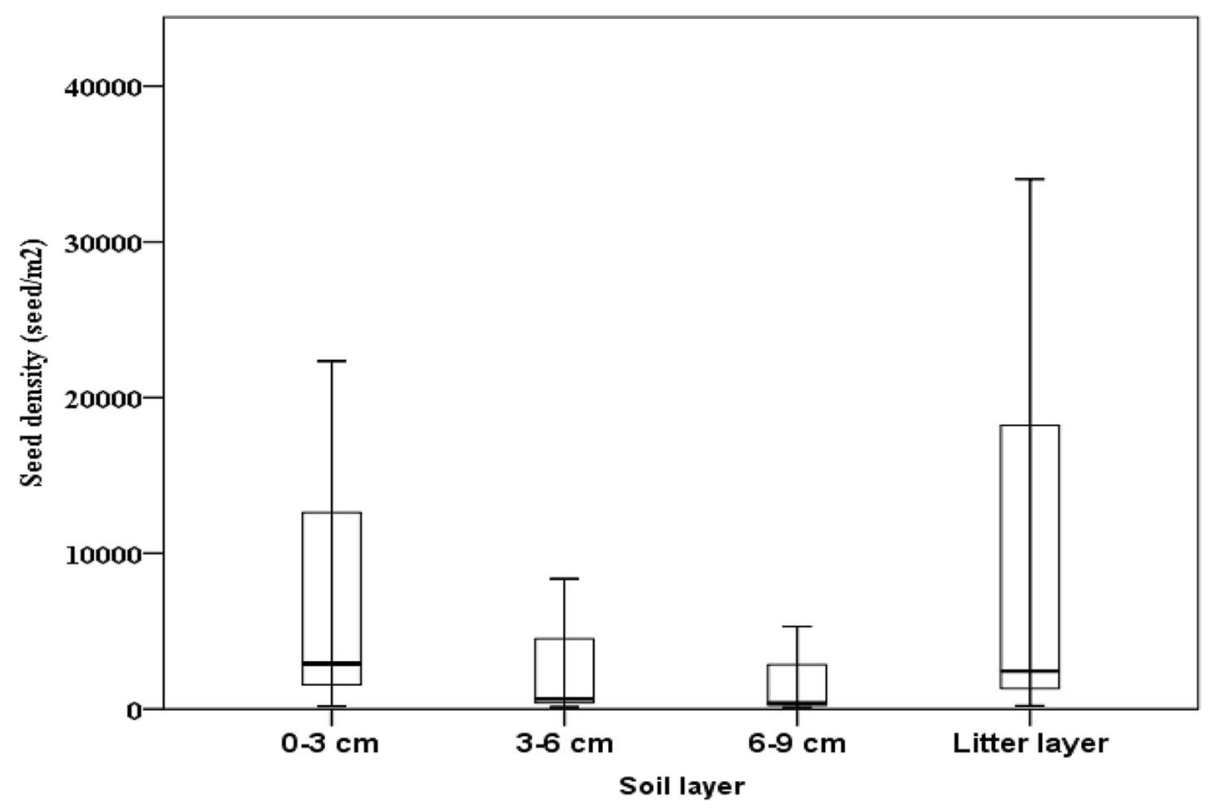

Fig. 3 The vertical distribution of density of soil seed bank

Moreover, the mean value of $R$ and $E^{\prime}$ at lower altitudes was also higher by $10.3 \%$ and $5.2 \%$, respectively than the upper altitudes. On the other hand, the mean values of $H^{\prime}$ at northwest and east-facing slopes were greater by $44.7 \%$ and $42.1 \%$, respectively than in the southeast. The mean values of $H^{\prime}$ at northwest and east were found to be greater than in the southwest. The mean values of $H^{\prime}$ at northwest and east were also higher by $31.4 \%$ and $28.3 \%$, respectively than in the northeast. Concerning the $R$ and $E^{\prime}$ values, similar trends of higher mean values were observed in the study areas. The mean value of slopes for $H^{\prime}$ and $R$ was the greatest at higher slopes. On the other hand, the mean values of $E^{\prime}$ were the greatest at slower slopes. But, the lowest mean values of $E^{\prime}$ were recorded at $6 \%$ slope. Results revealed that the overall trends of $H^{\prime}, R$, and $E^{\prime}$ were not consistent with slopes (Table 12 in Appendix).

Table 5 Biplot scores for constraining variables on soil seed bank patterns in South Afar region

\begin{tabular}{lllllll}
\hline $\begin{array}{l}\text { Environmental } \\
\text { variable }\end{array}$ & \multicolumn{6}{l}{ CCA axis } \\
\cline { 2 - 6 } & CCA1 & CCA2 & CCA3 & CCA4 & CCA5 & CCA6 \\
\hline Site & 0.71 & 0.65 & 0.13 & -0.04 & 0.05 & 0.14 \\
Habitat & -0.007 & 0.05 & -0.46 & -0.27 & 0.70 & 0.47 \\
Altitude & -0.44 & 0.03 & 0.67 & -0.17 & 0.51 & 0.19 \\
Human impact & -0.22 & 0.11 & 0.39 & 0.41 & -0.41 & 0.65 \\
Grazing intensity & -0.03 & -0.03 & 0.42 & 0.34 & -0.18 & 0.47 \\
Slope & 0.18 & -0.32 & 0.27 & -0.38 & -0.12 & 0.65 \\
Aspect & -0.13 & 0.47 & 0.01 & 0.18 & 0.009 & 0.29 \\
Disturbance & -0.22 & 0.14 & 0.42 & 0.07 & -0.14 & 0.57 \\
\hline
\end{tabular}

\section{Anthropogenic activities and soil seed bank diversity}

Results indicate that $H^{\prime}(F=2.168, P=0.09)$ and $E^{\prime}$ are significantly affected by human impacts; SSB patterns such as $R$ and $E^{\prime}$ were affected by human activities $(P<0.05)$. As a result, human impacts had shown significant effects on $R(F=8.921, P<0.0001)$ and $E^{\prime}(F=5.0, P<0.002)$. Moreover, grazing intensities had significant effects on $H^{\prime}$ $(F=26.12, P<0.0001), R(F=23.17, P<0.0001)$, and $E^{\prime}$ $(F=17.8, P<0.0001)$. Meanwhile, disturbance intensities had also significant effects on $H^{\prime}(F=22.97, P<0.0001)$, $R(F=17.64, P<0.0001)$, and $E^{\prime}(F=13.18, P<0.0001)$ in the study landscapes at $P<0.05$ (Table 10 in Appendix).

The variations in mean values of diversity indices between SSB patterns are shown in Table 13 in Appendix. For instance, the mean $R$ values of non-human impacted ones were higher than mean values of moderate and heavy impacts. Meanwhile, $R$ values of low disturbance were higher by $14.4 \%$ and $5.0 \%$ than moderate and heavy impacts, respectively. Moreover, the mean in $H^{\prime}$ values of relatively non-grazing zero grazing and low grazing intensities were greater by $6.6 \%$ and $10.5 \%$, respectively, from the moderately grazed ones (Table 12 in Appendix).

The mean values of zero grazing and low grazing were also higher by $24.8 \%$ and $28 \%$ respectively than under heavy grazing intensity. While similar trends in the values of $R$ were computed throughout the study landscapes the mean value in $E^{\prime}$ for moderately grazed areas was higher by $3.1 \%$ than under zero grazing and low grazed areas. But, moderate grazing was higher than heavy grazed areas in the study areas (Table 10 in Appendix).

With respect to disturbance intensity, the impact of mean zero disturbances for $H^{\prime}$ values were higher by 


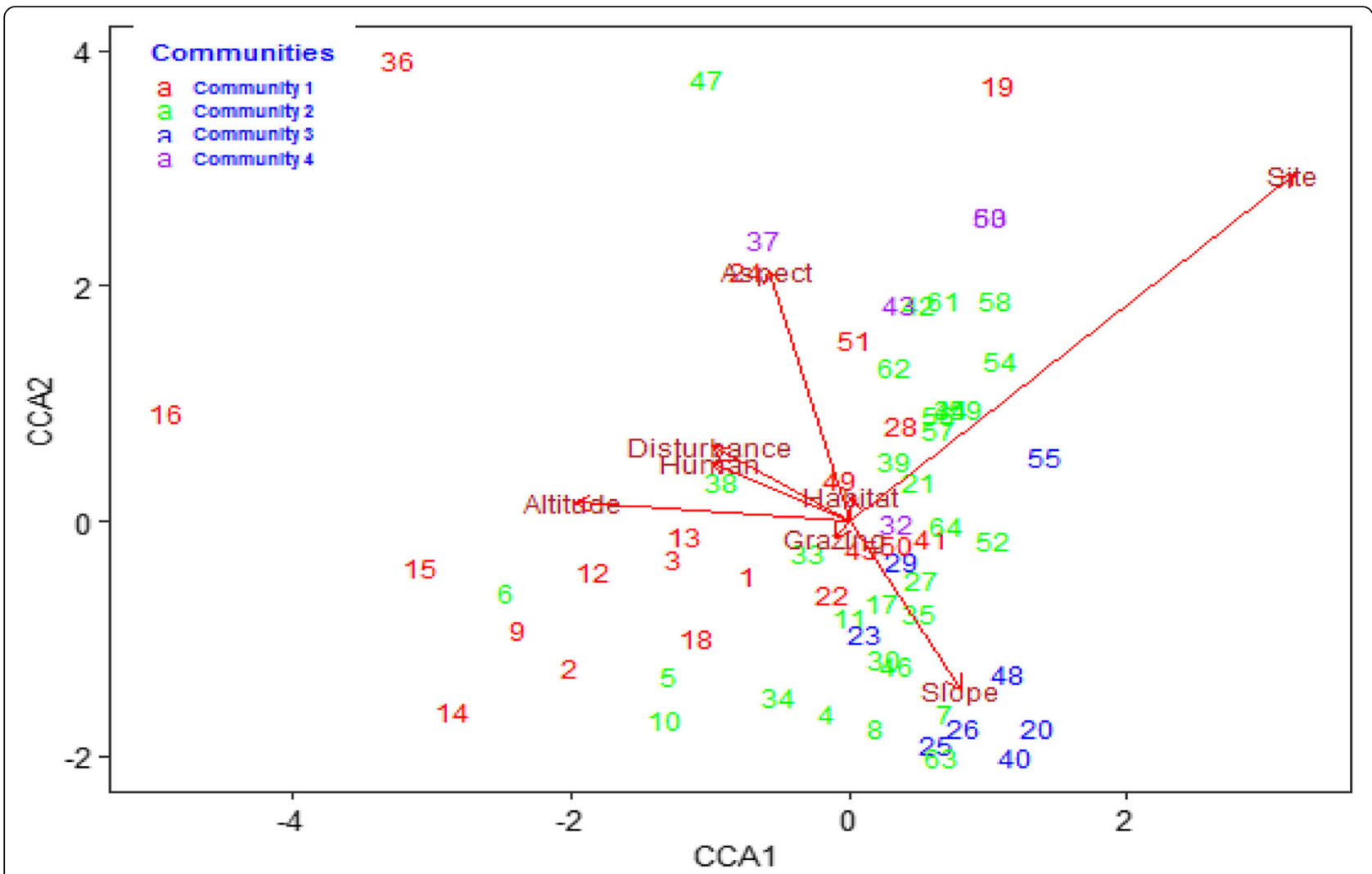

Fig. 4 CCA of sites constrained by some environmental variables (CCA1 is axis 1 and CCA2 axis 2)

$5.9 \%$ and $22.8 \%$ than under moderate and heavy disturbances respectively. Meanwhile, under low disturbance regime, $H^{\prime}$ value was higher by $9.9 \%$ and $26.1 \%$ than under moderate and heavy disturbances respectively.

On the other hand, the mean value of zero disturbances for $R$ was higher by $13.2 \%$ and $26.4 \%$ than under moderate and heavy disturbances. The mean values of low disturbances were also higher by $14.4 \%$ and $27.4 \%$ than moderate and heavy disturbances. But, the mean values of heavy disturbance in $E^{\prime}$ were lower by 5.3 , $6.3 \%$ and $6.3 \%$ than low, moderate, and heavy disturbances, respectively (Table 10 in Appendix).

Table 6 Sorensen similarity ratio between soil seed bank and extant vegetation

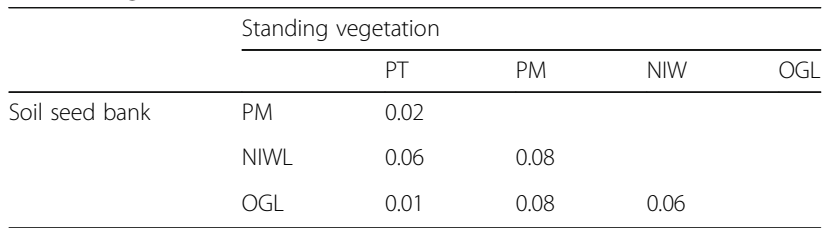

Notice: PT Prosopis thicket, PM Prosopis plus other indigenous species, NIWL non-invaded woodland, OGL open grazing land
Composition, density, and diversity of seeds in animal fecal matter

Analyses of ANOVA depicted that livestock had significant effects on $H^{\prime}, R$, and $E^{\prime}(F=23.3, P<0.001)$ of the seeds in soils at $P<0.05$ (Table 7 ). The mean $H^{\prime}$ value of seeds in shoats' fecal matter was higher than cattle but the mean value of $R$ in the fecal matter of cattle was higher by $20 \%$ than that of shoats. Moreover, the mean value in $E^{\prime}$ of shoats was higher by $27.7 \%$ than that of cattle in their fecal matter (Table 8).

Results revealed that the highest density of seeds in cattle fecal matter for Prosopis was 132 seeds/kg (78.6\%). The lowest proportion of seeds in cattle fecal matter was accounted for by Amaranthus thunbergii and Biden pilosa (3.6\%) collectively. The rest $(10.7 \%)$ is accounted for by $B$. leersioides. On the other hand, $3.6 \%$ of Prosopis were recovered from the fecal matter of shoats; $3.6 \%$ seeds $/ \mathrm{kg}$ were accounted for by Ipomoea indica and Ocimum urticifolium seeds. As a result, a large proportion of seeds $/ \mathrm{kg}$ (92.9\%) was recovered from cattle fecal matters. No seeds were recovered from camel fecal matter in the study landscapes (Table 9; Fig. 5).

\section{Discussion}

Effects of Prosopis invasion on species composition

The overall number of families and species in the SSB were far lower than that of aboveground flora in the 
Table 7 ANOVA showing effects of animals on seed patterns

\begin{tabular}{llllll}
\hline Model & Sum of squares & Df & Mean square & $F$ value & $P$ value \\
\hline$H^{\prime} \times$ livestock & 0.049 & 1 & 0.049 & 23.333 & $0.001^{*}$ \\
$R \times$ livestock & 1.867 & 1 & 1.867 & 23.333 & $0.001^{*}$ \\
$E^{\prime} \times$ livestock & 0.196 & 1 & 0.196 & 23.333 & $0.001^{*}$ \\
\hline
\end{tabular}

Notice: $H^{\prime}$ is the Shannon-Wiener index, $R$ is species richness, $E^{\prime}$ is the Shannon evenness; the same letters indicate insignificant variations at $P<0.05$

study areas. In the present study, the number of species in the SSB was comparable with a research report by Fengqin et al. (2017) but their findings show that less number of species and families in the aboveground flora were recorded than present results.

In our study, higher frequent families were recorded in SSB of non-invaded woodlands than habitats under Prosopis canopies such as Prosopis thicket and Prosopis with native species stands. This might be due to the allelopathic effects (Getachew et al., 2012; Mahdhi et al. 2018); the density of rhizobia organisms which able to nodulate Prosopis was higher than native nitrogen fixer species (Mahdhi et al. 2018) and its shading effects (Rotich 2016). These effects could favor the production of large amounts of seeds for Prosopis which had dominated other native species in Prosopis thicket and Prosopis with native species stands than non-invaded woodlands.

The seeds recovered in SSB were dominated by forbs and grass growth forms than woody species. These were due to shade-intolerant properties of the forbs and grass species (Shiferaw et al. 2018b). Furthermore, postdispersal processes such as predation and removal of seeds from the aboveground caused limitation in the viability of seeds of woody species (Salazar 2010). These findings were incomparable with a report made by Bekele (2000) in the dry Afromontane forest in South Wollo of Ethiopia. On the other hand, our findings were similar to SBs of dry seasons, but in contrast to SSB in the wet season of the report by Madawala et al. (2016). Furthermore, the number of growth forms in the form of forbs, climbers, and woody species had similar rends both in the forest relic and closed areas with that of research works by Reubens et al. (2007) in dry tropical forests of Northern Ethiopia. But, the number of graminoids recorded by the authors above was in contrast to the present study of Southern Afar Region. In

Table 8 Effects of livestock droppings on soil seed bank patterns

\begin{tabular}{llll}
\hline Livestock & $H^{\prime}$ & $R$ & $E^{\prime}$ \\
\hline Cattle & $0.94 \pm 0.00 \mathrm{a}$ & $4.0 \pm 0.0 \mathrm{a}$ & $0.68 \pm 0.0 \mathrm{~b}$ \\
Shoats & $1.07 \pm 0.03 \mathrm{~b}$ & $3.2 \pm 0.2 \mathrm{~b}$ & $0.94 \pm 0.06 \mathrm{a}$ \\
\hline
\end{tabular}

Notice: Shoats are sheep and goats, $H^{\prime}$ is the Shannon-Wiener index, $R$ is species richness, $E^{\prime}$ is the Shannon evenness; the same letters indicate insignificant variations at $P<0.05$ this study, plant species such as Amaranthus thunbergii, Alysicarpus rugosus, Physalis lagascae, Brachiaria leersioides, Ipomoea indica, Crotalaria pycnostachya, Euphorbia prostrate, and Ocimum urticifolium which were in the SSB but absent in the standing vegetation of study areas. The reason could be the effects intensity of grazing intensity and disturbances factors which had affected those species from standing vegetation.

In restoring degraded woodlands, the first step is to quantify the actual and potential levels of natural regeneration, examining the role of SSB as propagule contributor (Gul et al., 2012). The mean values of species diversity in terms of Shannon diversity index $\left(H^{\prime}\right)$ and species richness $(R)$ were declining in Prosopis-invaded patches than non-invaded woodlands. These were due to the allelopathic and shade effects of the species underneath Prosopis canopy which had reduced seed productivity. Furthermore, greater accumulation of litters underneath the Prosopis canopy could explain the greater inhibition of understory vegetation to produce seeds (El-Keblawy 2012; Kaur et al., 2012, El-Keblawy and Al-Rawai 2007; Muturi et al. 2013). Under high infestation of Prosopis, we recorded less species richness in SSB when we compare with Ilukor et al. (2016) findings in Gewane, Awash Fentale, and Amibara districts.

At Amibara district, both $H^{\prime}$ and species richness were higher than those of the Awash Fentale district. These were due to the moderate disturbance and grazing intensities acting upon the productivity of seeds to disperse and persist in $\mathrm{SB}$ at Amibara district in comparison with the lower grazing and disturbance intensities recorded at Awash Fentale district (Savadogo et al. 2016). Furthermore, at Awash Fentale, the dominance of few species for instance invasion of Prosopis attributes to lower in $H^{\prime}$ that produces seeds to land on/ in the soil (Singh et al., 2008; Kumar and Mathur, 2014). The highest values of $H^{\prime}$ under moderate disturbance might be due to favorable environmental variables that enhance the growth of a variety of plants in an ecosystem (Gautam et al. 2016). Our results were also in line with findings made by Biswas and Malik (2010) in riparian and upland plant communities of Canada. The level in the effects of disturbance on species diversity in our study was also comparable with a multi-trophic perspective of Wootton (1998).

\section{Spatial variations of soil seed diversity}

In this study, at Kebena of Awash Fentale, $H^{\prime}$ values recorded were the highest of all sites. On the other hand, when we look at specific sites in the study landscapes, the $N$ of Kurkura site at Amibara district was the highest of all sites. But, the Sedihafeghe site at Amibara district had the highest $E^{\prime}$ values of the species in the study area. These various in $H^{\prime}, R$, and $E^{\prime}$ could be due to the variations in Prosopis infestation, anthropogenic effects, and disturbance intensities in the sites (Li et al. 2017). 
Table 9 Distribution of seeds types in animal droppings

\begin{tabular}{|c|c|c|c|c|c|}
\hline Animals & $\begin{array}{l}\text { Scientific } \\
\text { name }\end{array}$ & $\begin{array}{l}\text { Number of } \\
\text { animals }\end{array}$ & $\begin{array}{l}\text { SD abundance/ } \\
0.5 \mathrm{~kg}\end{array}$ & $\begin{array}{l}\text { SSD density/ } \\
\mathrm{kg}\end{array}$ & $\%$ \\
\hline \multirow[t]{4}{*}{ Cattle } & B. pilosa & & 2 & 4 & 2.4 \\
\hline & P. juliflora & 50 & 66 & 132 & 78.6 \\
\hline & B. leersioides & & 9 & 18 & 10.7 \\
\hline & A. thunbergii & & 1 & 2 & 1.2 \\
\hline \multirow[t]{3}{*}{ Shoats } & I. indica & 150 & 2 & 4 & 2.4 \\
\hline & P. juliflora & & 3 & 6 & 3.6 \\
\hline & $\begin{array}{l}\text { O. } \\
\text { urticifolium }\end{array}$ & & 1 & 2 & 1.2 \\
\hline Total & & & 84 & 168 & 100.0 \\
\hline
\end{tabular}

Though soil layer did not have negatively affects $H^{\prime}$ and $R$ of SBs in the study areas, the highest $H^{\prime}$ and $R$ were recorded in the lower soil layer of $6-9 \mathrm{~cm}$. The reason might be due to the small size and elongated seeds those moved down to the subsoil and persistent in the soil (Moles et al. 2000; Peco et al. 2003; Eager et al. 2013; Shiferaw et al. 2018b). Moreover, in the upper soil, lack of thick litter might expose the seeds for winds, germination, and predators in the study areas (Argaw et al. 1999; Bueno and Baruch 2011; Egawa and Tsuyuzaki, 2013).

Our finding found that $R$ of SB was similar to a research report made by $\mathrm{Li}$ et al. (2017) in a semi-arid region of
Northern China but in contrast to the results suggested by Qian et al. (2016) in Northeastern Inner Mongolia of China. However, the distribution of seeds vertically in the soil was equal and did not affect the variations in $E^{\prime}$ in the study areas. The reason could be due to the declining of soil disturbances down the soil layers (Olano et al. 2012).

\section{Status of soil seed density}

Vertically down the soil layers, the density of seedlings germinated from soil samples in the greenhouse was declined. This pattern is assumed as regular seed inputs at the surface and a more or less gradual decline in viability as seeds aged and move vertically down soil profiles (Shiferaw et al. 2018b). Our findings were similar trends with that of SSB density distribution patterns with Cox and Allen (2008) in Southern California coastal sage scrub and adjacent exotic grassland. However, the density of SSB for Prosopis species was far less than that of reports made by Shiferaw et al. (2004) in the litter layer in Middle Awash Rift Valley Area in Northeastern Ethiopia. These variations in the density of Prosopis could be due to seasonal effects and random spatial distribution of seeds in the soil samples. In the present study, the total density of SSB was far greater than reports made by Maranon (1998) in the annual-dominated Mediterranean salt marsh and

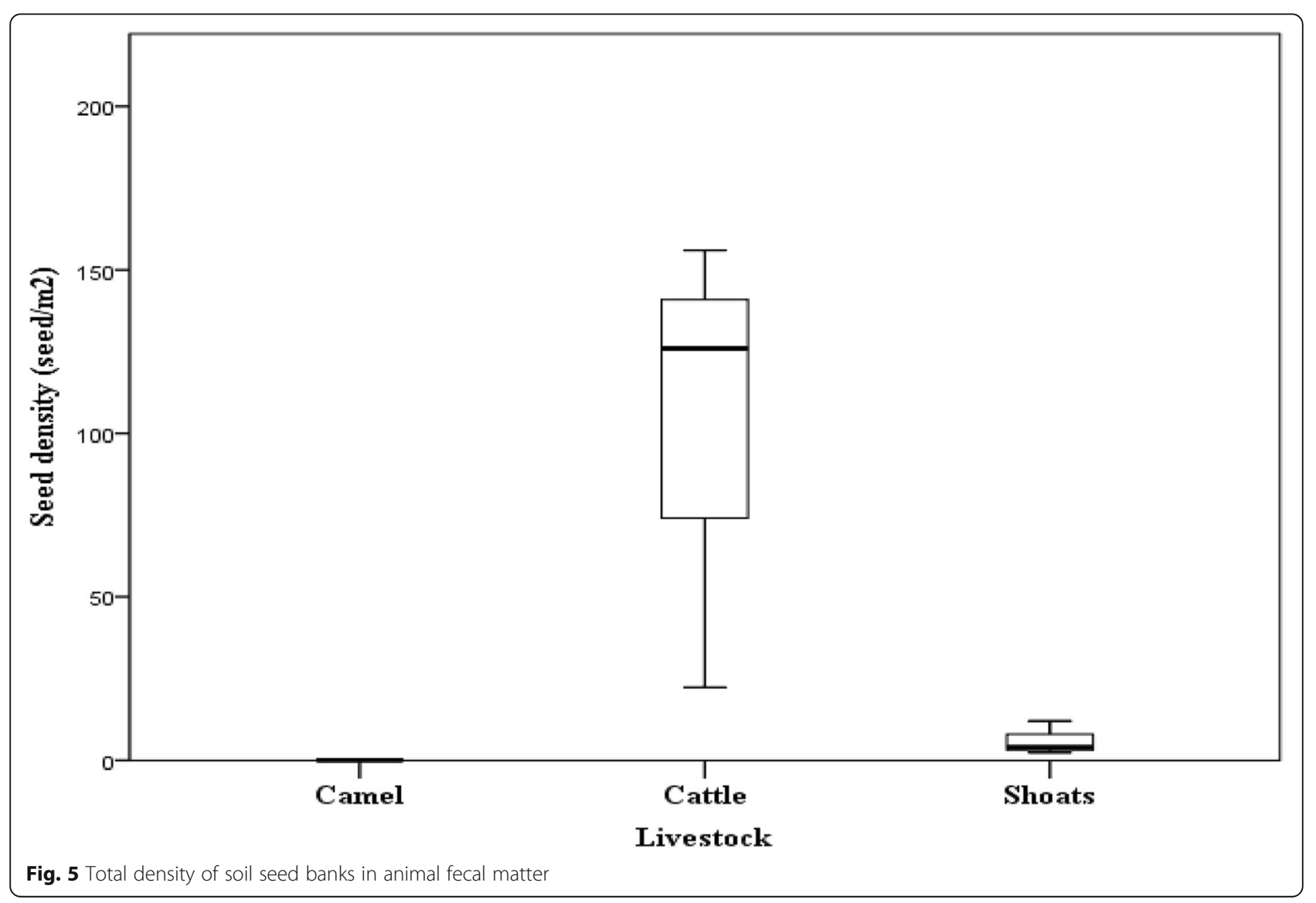


was also higher than reports by Li et al. (2017) in the semi-arid region of Northern China.

Moreover, the density of SSB in our findings was greater than for both season research findings by Kellerman and Van Rooyen (2007; pp. 252) in selected habitat types in the Maputa Land of South Africa. However, the densities of the SSB in the present findings were far less than the density of the SSB by Dreber (2011) in arid rangelands of the Nama Karoo of Sothern Africa.

Our results showed that seeds recovered from soil samples were showed low similarity with the standing vegetation in both of the habitats and the least similarity was recorded between Prosopis thicket and Prosopis with native species stands, and Prosopis thicket and open grazing lands. Only three species such as C. ciliaris, $P$. hysterophorus, and Prosopis under Prosopis thicket and Prosopis with native species stands of SSB were common to the same habitats of standing vegetation. Whereas, four species such as L. martinicensis, Solanum. incanum, C. ciliaris, P. hysterophorus, and Prosopis under noninvaded woodlands of SBB were similar to (shared species) non-invaded woodlands of standing vegetation.

On the other hand, L. martinicensis, P. hysterophorus, and Prosopis were similar with open grazing lands in SSB and standing vegetation. The reason might be due to the variations in the persistence of the seeds that contributed to vegetation composition of the standing vegetation and belowground flora (Hopfensperger 2007; Gioria and Pysek 2016). Moreover, the dissimilarity between aboveground and belowground flora might also be due to the effects of grazing (Chaideftou et al. 2009) and increased disturbance intensities (Li et al. 2017).

Our findings were similar with studies reported to Sileshi and Abraha (2014) at Ksadaider and Bandra forest sites in the Hgumbirda National Forest Priority Area of Northeastern Ethiopia and Limenih and Teketay (2006) in tropical dry Afromontane natural forest of Ethiopia. However, in the present study, patterns of similarity between aboveground and belowground flora were different from the results of Koch et al. (2011) in the limestone grasslands, Valko et al. (2011) in the drymesophyllous grasslands, and Sanou et al. (2018) around the savanna woodland watering point in West Africa.

Our results suggested that both SB patterns $\left(H^{\prime}, R\right.$, and $E^{\prime}$ ) were highly affected at higher altitudes than the lower altitudes because, at higher elevations, temperature, wind, and soil instability may limit plant growth (Shaheen et al. 2015; da Luz et al. 2017). Furthermore, more various types of seeds may be correlated with the density of the aboveground vegetation which existed in the lower altitudes (Cheng et al. 2001; Valko et al. 2014). However, findings by Espinosa et al. (2013) suggested that species richness is declined with increasing altitude which contradicts our results.
In this study, the $\mathrm{SBs}$ in $H^{\prime}, R$, and $E^{\prime}$ were significantly decreased at other aspects than northwest and east facings of the study areas. These could be due to the effects of easterlies wind which had caused the seed rain to land on these facings. Moreover, due to the higher amount of solar radiation received and, consequently, the increased air and soil temperature on the east-facing slopes had increased species diversity in the aboveground flora which had also favored the diverse and abundances of seeds in the soil (Yirdaw et al., 2015).

The highest $H^{\prime}$ and $E^{\prime}$ might also be due to the environmental suitability such as high moisture and soil fertility favored the above vegetation flora in east and northwest facings (Chapman and McEwan 2018). Geomorphic position, aspect, and micro-slope affect species richness and soil seed banks primarily through modulating soil water availability and soil erosion susceptibility might also be the cause for the decline in the either of the slope position except for the east and northwest facings (Fengqin et al. 2017).

Our results showed that not clear variations in $H^{\prime}, R$, and $E^{\prime}$ of vegetation patterns observed in the study areas. The reason might be due to insignificant variations in the topography of the study landscapes in the Southern Afar Region. However, in general, variations in slopes of an area indirectly detected the variations in moisture and soil fertility which as the result affects the density of aboveground and SBs as well (Chapman and McEwan 2018).

In this study, both diversity indices $\left(H^{\prime}, R\right.$, and $\left.E^{\prime}\right)$ were increased as the human disturbance activities declined. The reason might be due to the increasing intensity of anthropogenic effects in terms of grazing and selective cutting of the woody species in the study areas (Tsegaye et al., 2010). Our findings were similar trends with results of the Li et al. (2017) in the semi-arid region of Northern China and Marcelo et al. (2003) at the Karei Deshe Experimental Farm, located in Northeastern Israel. Other findings by the Arevalo-Sandi et al. (2018) also suggest that the loss of species richness and functional diversity were increasing with the level of intensity of disturbances.

\section{Seed dispersal and density in animal fecal droppings}

Seed dispersal has implications for the understanding of fundamental and applied questions concerning invasive plant spread and ecological restoration (Mouissie et al. 2005). The diversity of seeds in the fecal matter of shoats was higher than cattle but the seeds $R$ were higher in cattle fecal matters, and the highest fecal seed density of Prosopis was recovered from cattle fecal matters. The reasons for higher seed $H^{\prime}$ might be due to shoats feeding habits which are different from that of cattle. That means shoats are both browsers and grazers. Other reasons might also be due to the smaller seeds which increase survival rate during gut passage in greater numbers than larger seeds in cattle gut which had contributed for high $R$ (Bruun and 
Poschlod 2006). However, cattle are selective for grazing and which feed usually on grass species. Furthermore, cattle are feeding large quantities of biomass which might also cause for $R$ higher. Among the dispersers, in the cattle fecal matter, the higher overall density of seeds per kilogram was recorded than in shoats' fecal matters. This idea was confirmed by a study of Bilal (2015) in the Netherlands. On the other hand, cattle are usually fed on Prosopis pods which had dropped on the floor of woody species. These findings were similar to the report of Mworia et al. (2011) in the riverine woodlands of upper floodplain at the Tana River in Kenya.

\section{Conclusions}

In this study, the lower $R$ was recorded in Prosopis invasion habitats (Prosopis thicket and Prosopis with native species stands) than that of non-invaded woodlands and open grazing lands. Similar to species richness $(R)$, less number of growth forms were also recorded Prosopis-invaded habitats. These indicated that invasion of the Prosopis had adverse effects on the growth of plant Shannon diversity index $\left(H^{\prime}\right)$ which ultimately affects ecosystem services by other native plant species. Our results also depicted that $H^{\prime}$ and $R$ were declined as Prosopis invasion severity increases. However, the species evenness $\left(E^{\prime}\right)$ of each species under Prosopis with native species stands and open grazing lands were relatively evenly distributed than Prosopis thicket and noninvaded woodlands. These showed the monoculture growth of Prosopis and other invasive acacia species like A. mellifera and A. Senegal under Prosopis thicket and non-invaded woodlands, respectively. These had also implications for the loss of native species in $H^{\prime}$, e.g., desirable grasses. The displacement of open grazing lands by Prosopis thicket had threatened not only the agro-pastoralists' prime grazing lands for livestock but also the survival of wildlife in national parks and other conservation areas in the region.

The composition and density of the seeds recovered from soil samples were also variable spatially and down soil layers. For instance, the $H^{\prime}$ of SBs at Kebena site of Awash Fentale district was the highest of all sites. This implied that the severity of the invasion of Prosopis and other woody species at Kurkura, Dudub, and Sedihafeghe sites need attention for sustainable management. The seeds $H^{\prime}$ and $R$ recovered from the lower soil depth in $6-9 \mathrm{~cm}$ were the highest of other soil layers. These were indications of the persistence of the seeds down the soil layers. Lack of thick litter could also be exposed the seeds to predators and other abiotic dispersers such as winds and soil erosion.

On the other hand, our results also revealed that the density of seeds in the soil was declined down the soil layers and Prosopis seeds were the highest in the litter layer of all the soil layers. Furthermore, Brachiaria leersioides, Parthenium hysterophorus, and Eragrostis aethiopica seeds were also among the species in which large numbers of seeds recovered from the litter layer. These findings depicted the large productivity of these seeds which had dispersed near their parent plants.

However, relatively larger amounts of seeds where recovered from the lower soil layers except Prosopis was absent in the lower soil layers. These had implications for the small size of the seeds to persist in the soil for other species but further investigation will be needed for Prosopis and other species such as Prosopis, Solanum incanum, T. simense, P. crispus, C. grandis, Fuirena leptostachya, H. longiflorum, C. ciliaris, I. indica, and C. pycnostachya in the study landscapes.

Concerning seeds in the soil and standing vegetation, Sorensen's coefficient revealed the lowest similarity. These had also indicated for the loss and degradation of belowground flora of the grass and woodlands. Thus, these losses and other underlying effects of drought might delay the natural restoration of vegetation in the region.

In the present study, both soil seed patterns in terms of $H^{\prime}, R$, and $E^{\prime}$ were declined in the higher altitude ranges than lower altitudinal ranges. These indicated that seed loss from higher altitudinal areas perhaps moves down the lower areas by wind and gravitational forces. Meanwhile, at the heavy intensity of anthropogenic, grazing and disturbance effects $R$ and $H^{\prime}$ were also decreased. Our findings had thus implications of minimizing the wise utilization of vegetation and balancing the carrying capacity of the rangelands.

Our results also revealed that cattle were the most diverse seed dispersal agents and disseminating the large amounts of individual plant seeds and Prosopis in the study landscapes. These ideas implicated that large progression of Prosopis into woodlands and prime grazing lands induced seed dispersal largely by cattle and then shoats fecal matter which easily emerged after the seeds passed through their guts.

Thus, management of Prosopis is possible by the utilization of the species and minimize seed dispersal through aborting its reproduction early in the flowering times is highly recommended. To minimize the adverse effects of Prosopis on the native species, appropriate silvicultural management practices such as thinning, pollarding, and pruning can also be applied. As the seeds in the soil were low in the study areas, in situ and ex situ conservation of original plants and reseeding of persistent grass species such as Cynodon dactylon, Cenchrus ciliaris, Chrysopogon plumulosus, and Brachiaria ramosa are highly recommended. Creating awareness for stakeholders about the history, cause, and impacts invasive species on native plant species is very important. Multidisciplinary approaches of the natural resources managers for sustainable management of the rangeland in the region are also vital to reverse the situations. 


\section{Appendix}

Table 10 ANOVA showing the effects of locations, Prosopis invasiveness, a soil layer, physiographic and human activities on soil seed patterns in South Afar, Ethiopia

\begin{tabular}{|c|c|c|c|c|c|}
\hline Model & Sum of squares & Df & Mean square & $F$ value & $P$ value \\
\hline $\mathrm{H}^{\prime *}$ district & 1.982 & 1 & 1.982 & 13.053 & $0.0002^{* *}$ \\
\hline$R^{*}$ district & 56.193 & 1 & 56.193 & 21.85 & $<0.0001^{* * *}$ \\
\hline$E^{\prime *}$ district & 0.061 & 1 & 0.061 & 8.381 & $0.004^{* *}$ \\
\hline $\mathrm{H}^{\prime *}$ site & 10.138 & 3 & 3.379 & 25.281 & $<0.0001^{* * *}$ \\
\hline$R^{*}$ site & 214.113 & 3 & 71.371 & 32.164 & $<0.0001^{* * *}$ \\
\hline$E^{\prime *}$ site & 0.518 & 3 & 0.173 & 27.461 & $<0.0001^{* * *}$ \\
\hline $\mathrm{H}^{\prime *}$ habitat & 6.153 & 3 & 2.051 & 14.355 & $<0.0001^{* * *}$ \\
\hline $\mathrm{R} *$ habitat & 127.473 & 3 & 42.491 & 17.565 & $<0.0001^{* * *}$ \\
\hline$E^{\prime *}$ habitat & 0.003 & 3 & 0.001 & 0.119 & 0.95 \\
\hline $\mathrm{H}^{\prime *}$ soil layer & 0.166 & 3 & 0.055 & 0.353 & 0.79 \\
\hline$R^{*}$ soil layer & 3.024 & 3 & 1.008 & 0.372 & 0.77 \\
\hline $\mathrm{E}^{\prime *}$ soil layer & 0.009 & 3 & 0.003 & 0.422 & 0.74 \\
\hline $\mathrm{H}^{\prime *}$ altitude & 2.988 & 2 & 1.494 & 9.971 & $<0.0001^{* * *}$ \\
\hline$R *$ altitude & 20.422 & 2 & 10.211 & 3.839 & $0.02^{*}$ \\
\hline$E^{\prime *}$ altitude & 0.209 & 2 & 0.104 & 14.965 & $<0.0001^{* * *}$ \\
\hline $\mathrm{H}^{\prime *}$ slope & 14.071 & 11 & 1.279 & 10.078 & $<0.0001^{* * *}$ \\
\hline$R$ * slope & 289.955 & 11 & 26.36 & 12.659 & $<0.0001^{* * *}$ \\
\hline$E^{\prime *}$ slope & 1.633 & 11 & 0.148 & 39.31 & $<0.0001^{* * *}$ \\
\hline $\mathrm{H}^{\prime *}$ aspect & 18.829 & 7 & 2.69 & 23.459 & $<0.0001^{* * *}$ \\
\hline $\mathrm{R}^{*}$ aspect & 453.399 & 7 & 64.771 & 38.512 & $<0.0001^{* * *}$ \\
\hline$E^{\prime *}$ aspect & 0.73 & 7 & 0.104 & 17.851 & $<0.0001^{* * *}$ \\
\hline $\mathrm{H}^{\prime *}$ human impact & 1.007 & 3 & 0.336 & 2.168 & 0.09 \\
\hline$R$ * human impact & 68.392 & 3 & 22.797 & 8.921 & $<0.0001^{* * *}$ \\
\hline $\mathrm{E}^{\prime *}$ human impact & 0.108 & 3 & 0.036 & 5.003 & $0.002^{* *}$ \\
\hline $\mathrm{H}^{\prime *}$ grazing intensity & 10.423 & 3 & 3.474 & 26.119 & $<0.0001^{* * *}$ \\
\hline$R$ * grazing intensity & 162.528 & 3 & 54.176 & 23.171 & $<0.0001^{* * *}$ \\
\hline$E^{\prime *}$ grazing intensity & 0.355 & 3 & 0.118 & 17.792 & $<0.0001^{* * *}$ \\
\hline $\mathrm{H}^{\prime *}$ disturbance intensity & 9.338 & 3 & 3.113 & 22.968 & $<0.0001^{* * *}$ \\
\hline$R$ * disturbance intensity & 127.942 & 3 & 42.647 & 17.638 & $<0.0001^{* * *}$ \\
\hline $\mathrm{E}^{\prime *}$ disturbance intensity & 0.271 & 3 & 0.09 & 13.178 & $<0.0001^{* * *}$ \\
\hline
\end{tabular}

Notice: $H^{\prime}$ is the Shannon-Wiener index, $R$ is species richness, $E^{\prime}$ is the Shannon evenness, Prosopis invasion levels/habitats (PT, PM, NIWL, and OGLs), Df is the degree of freedom, ${ }^{*}$ significant at $P<0.05,{ }^{* *}$ is the high significant at $P<0.05,{ }^{* * *}$ is the very high significant at $P<0.05$; the same letters indicate insignificant variations at $P<0.05$ 
Table 11 Species richness and composition under different Prosopis invasion levels (habitats)

\begin{tabular}{|c|c|c|c|c|}
\hline Species richness & Habitat & Scientific name & Life form & Family \\
\hline 1 & PT & Amaranthus thunbergii & Forb & Amaranthaceae \\
\hline 2 & PT & Bidens pilosa & Forb & Asteraceae \\
\hline 3 & PT & Brachiaria leersioides & Herb & Poaceae \\
\hline 4 & PT & Cenchrus ciliaris & Herb & Poaceae \\
\hline 5 & PT & Coccinia grandis & Climber & Cucurbitaceae \\
\hline 6 & PT & Eragrostis aethiopica & Herb & Poaceae \\
\hline 7 & PT & Ipomoea indica & Climber & Convolvulaceae \\
\hline 8 & PT & Ocimum spicatum & Forb & Lamiaceae \\
\hline 9 & PT & Parthenium hysterophorus & Forb & Asteraceae \\
\hline 10 & PT & Physalis lagascae & Forb & Solanaceae \\
\hline 11 & PT & Prosopis juliflora & Tree/shrub & Fabaceae \\
\hline 1 & PM & Amaranthus thunbergii & Forb & Amaranthaceae \\
\hline 2 & PM & Bidens pilosa & Forb & Asteraceae \\
\hline 3 & PM & Brachiaria leersioides & Herb & Poaceae \\
\hline 4 & PM & Cenchrus ciliaris & Herb & Poaceae \\
\hline 5 & PM & Eragrostis aethiopica & Herb & Poaceae \\
\hline 6 & PM & Fuirena leptostachya & Herb & Cyperaceae \\
\hline 7 & PM & Ocimum spicatum & Forb & Lamiaceae \\
\hline 8 & PM & Parthenium hysterophorus & Forb & Asteraceae \\
\hline 9 & PM & Physalis lagascae & Forb & Solanaceae \\
\hline 10 & PM & Trifolium simense & Forb & Fabaceae \\
\hline 1 & NIWL & Amaranthus thunbergii & Forb & Amaranthaceae \\
\hline 2 & NIWL & Bidens pilosa & Forb & Asteraceae \\
\hline 3 & NIWL & Brachiaria leersioides & Herb & Poaceae \\
\hline 4 & NIWL & Cenchrus ciliaris & Herb & Poaceae \\
\hline 5 & NIWL & Coccinia grandis & Climber & Cucurbitaceae \\
\hline 6 & NIWL & Crotalaria pycnostachya & Forb & Fabaceae \\
\hline 7 & NIWL & Eragrostis aethiopica & Herb & Poaceae \\
\hline 8 & NIWL & Fuirena leptostachya & Forb & Cyperaceae \\
\hline 9 & NIWL & Leucas martinicensis & Forb & Lamiaceae \\
\hline 10 & NIWL & Ocimum spicatum & Forb & Lamiaceae \\
\hline 11 & NIWL & Parthenium hysterophorus & Forb & Asteraceae \\
\hline 12 & NIWL & Physalis lagascae & Forb & Solanaceae \\
\hline 13 & NIWL & Ipomoea blepharophylla & Forb & Convolvulaceae \\
\hline 14 & NIWL & Solanum incanum & Forb & Solanaceae \\
\hline 15 & NIWL & Trifolium simense & Forb & Fabaceae \\
\hline 1 & OGL & Amaranthus thunbergii & Forb & Amaranthaceae \\
\hline 2 & OGL & Bidens pilosa & Forb & Asteraceae \\
\hline 3 & OGL & Brachiaria leersioides & Herb & Poaceae \\
\hline 4 & OGL & Cenchrus ciliaris & Herb & Poaceae \\
\hline 5 & OGL & Eragrostis aethiopica & Herb & Poaceae \\
\hline 6 & OGL & Leucas martinicensis & Forb & Lamiaceae \\
\hline 7 & OGL & Ocimum spicatum & Forb & Lamiaceae \\
\hline 8 & OGL & Parthenium hysterophorus & Forb & Asteraceae \\
\hline 9 & OGL & Physalis lagascae & Forb & Solanaceae \\
\hline 10 & OGL & Alysicarpus rugosus & Forb & Potamogetonaceae \\
\hline 11 & OGL & Prosopis juliflora & Tree/shrub & Fabaceae \\
\hline 12 & OGL & Ziziphus spina-christi & Tree & Rhamnaceae \\
\hline
\end{tabular}


Table 12 Vertical soil seed bank composition, abundance, density, and IV

\begin{tabular}{|c|c|c|c|c|c|c|c|c|c|c|c|}
\hline Soil layer & Species & $\mathrm{Ab}$ & $\mathrm{SBD} / \mathrm{m}^{2}$ & $F$ & $\mathrm{AF}$ & $R_{1}$ & $\mathrm{AD}$ & $R_{2}$ & Aab & $R_{3}$ & $I_{\mathrm{VI}}$ \\
\hline Litter & Amaranthus thunbergii & 39 & 1733 & 10 & 0.04 & 2.34 & 6.77 & 2.37 & 3.90 & 3.07 & 7.79 \\
\hline Litter & Bidens pilosa & 33 & 1467 & 19 & 0.07 & 4.45 & 5.73 & 2.01 & 1.74 & 1.37 & 7.83 \\
\hline Litter & Brachiaria leersioides & 300 & 13333 & 64 & 0.25 & 14.99 & 52.08 & 18.26 & 4.69 & 3.69 & 36.94 \\
\hline Litter & Cenchrus ciliaris & 43 & 1911 & 6 & 0.02 & 1.41 & 7.47 & 2.62 & 7.17 & 5.64 & 9.67 \\
\hline Litter & Coccinia grandis & 3 & 133 & 2 & 0.01 & 0.47 & 0.52 & 0.18 & 1.50 & 1.18 & 1.83 \\
\hline Litter & Crotalaria pycnostachya & 1 & 44 & 1 & 0.00 & 0.23 & 0.17 & 0.06 & 1.00 & 0.79 & 1.08 \\
\hline Litter & Eragrostis aethiopica & 128 & 5689 & 12 & 0.05 & 2.81 & 22.22 & 7.79 & 10.67 & 8.40 & 19.00 \\
\hline Litter & Fuirena leptostachya & 3 & 133 & 3 & 0.01 & 0.70 & 0.52 & 0.18 & 1.00 & 0.79 & 1.67 \\
\hline Litter & Ipomoea indica & 4 & 178 & 3 & 0.01 & 0.70 & 0.69 & 0.24 & 1.33 & 1.05 & 2.00 \\
\hline Litter & Leucas martinicensis & 4 & 178 & 2 & 0.01 & 0.47 & 0.69 & 0.24 & 2.00 & 1.57 & 2.29 \\
\hline Litter & Ocimum spicatum & 35 & 1556 & 17 & 0.07 & 3.98 & 6.08 & 2.13 & 2.06 & 1.62 & 7.73 \\
\hline Litter & Parthenium hysterophorus & 139 & 6178 & 23 & 0.09 & 5.39 & 24.13 & 8.46 & 6.04 & 4.76 & 18.61 \\
\hline Litter & Physalis lagascae & 20 & 889 & 9 & 0.04 & 2.11 & 3.47 & 1.22 & 2.22 & 1.75 & 5.07 \\
\hline Litter & Alysicarpus rugosus & 2 & 89 & 2 & 0.01 & 0.47 & 0.35 & 0.12 & 1.00 & 0.79 & 1.38 \\
\hline Litter & Prosopis juliflora & 5 & 222 & 3 & 0.01 & 0.70 & 0.87 & 0.30 & 1.67 & 1.31 & 2.32 \\
\hline Litter & Solanum incanum & 1 & 44 & 1 & 0.00 & 0.23 & 0.17 & 0.06 & 1.00 & 0.79 & 1.08 \\
\hline Litter & Trifolium simense & 1 & 44 & 2 & 0.01 & 0.47 & 0.17 & 0.06 & 0.50 & 0.39 & 0.92 \\
\hline Litter & Ziziphus spina-christi & 2 & 89 & 1 & 0.00 & 0.23 & 0.35 & 0.12 & 2.00 & 1.57 & 1.93 \\
\hline $0-3 \mathrm{~cm}$ & Amaranthus thunbergii & 19 & 844 & 11 & 0.04 & 2.58 & 3.30 & 1.16 & 1.73 & 1.36 & 5.09 \\
\hline $0-3 \mathrm{~cm}$ & Bidens pilosa & 35 & 1556 & 12 & 0.05 & 2.81 & 6.08 & 2.13 & 2.92 & 2.30 & 7.24 \\
\hline $0-3 \mathrm{~cm}$ & Brachiaria leersioides & 319 & 14178 & 53 & 0.21 & 12.41 & 55.38 & 19.42 & 6.02 & 4.74 & 36.57 \\
\hline $0-3 \mathrm{~cm}$ & Cenchrus ciliaris & 12 & 533 & 3 & 0.01 & 0.70 & 2.08 & 0.73 & 4.00 & 3.15 & 4.58 \\
\hline $0-3 \mathrm{~cm}$ & Coccinia grandis & 1 & 44 & 1 & 0.00 & 0.23 & 0.17 & 0.06 & 1.00 & 0.79 & 1.08 \\
\hline $0-3 \mathrm{~cm}$ & Crotalaria pycnostachya & 5 & 222 & 4 & 0.02 & 0.94 & 0.87 & 0.30 & 1.25 & 0.98 & 2.23 \\
\hline $0-3 \mathrm{~cm}$ & Eragrostis aethiopica & 60 & 2667 & 13 & 0.05 & 3.04 & 10.42 & 3.65 & 4.62 & 3.63 & 10.33 \\
\hline $0-3 \mathrm{~cm}$ & Fuirena leptostachya & 1 & 44 & 1 & 0.00 & 0.23 & 0.17 & 0.06 & 1.00 & 0.79 & 1.08 \\
\hline $0-3 \mathrm{~cm}$ & Heliotropium zeylanicum & 1 & 44 & 1 & 0.00 & 0.23 & 0.17 & 0.06 & 1.00 & 0.79 & 1.08 \\
\hline $0-3 \mathrm{~cm}$ & Ocimum spicatum & 19 & 844 & 9 & 0.04 & 2.11 & 3.30 & 1.16 & 2.11 & 1.66 & 4.93 \\
\hline $0-3 \mathrm{~cm}$ & Parthenium hysterophorus & 102 & 4533 & 15 & 0.06 & 3.51 & 17.71 & 6.21 & 6.80 & 5.35 & 15.08 \\
\hline $0-3 \mathrm{~cm}$ & Physalis lagascae & 2 & 89 & 2 & 0.01 & 0.47 & 0.35 & 0.12 & 1.00 & 0.79 & 1.38 \\
\hline $0-3 \mathrm{~cm}$ & Alysicarpus rugosus & 1 & 44 & 1 & 0.01 & 0.47 & 0.17 & 0.06 & 0.50 & 0.39 & 0.92 \\
\hline $0-3 \mathrm{~cm}$ & Trifolium simense & 4 & 178 & 3 & 0.01 & 0.70 & 0.69 & 0.24 & 1.33 & 1.05 & 2.00 \\
\hline $3-6 \mathrm{~cm}$ & Amaranthus thunbergii & 23 & 1022 & 7 & 0.03 & 1.64 & 3.99 & 1.40 & 3.29 & 2.59 & 5.63 \\
\hline $3-6 \mathrm{~cm}$ & Bidens pilosa & 6 & 267 & 5 & 0.02 & 1.17 & 1.04 & 0.37 & 1.20 & 0.94 & 2.48 \\
\hline $3-6 \mathrm{~cm}$ & Brachiaria leersioides & 74 & 3289 & 25 & 0.10 & 5.85 & 12.85 & 4.50 & 2.96 & 2.33 & 12.69 \\
\hline $3-6 \mathrm{~cm}$ & Cenchrus ciliaris & 1 & 44 & 1 & 0.00 & 0.23 & 0.17 & 0.06 & 1.00 & 0.79 & 1.08 \\
\hline $3-6 \mathrm{~cm}$ & Crotalaria pycnostachya & 2 & 89 & 2 & 0.01 & 0.47 & 0.35 & 0.12 & 1.00 & 0.79 & 1.38 \\
\hline $3-6 \mathrm{~cm}$ & Eragrostis aethiopica & 6 & 267 & 5 & 0.02 & 1.17 & 1.04 & 0.37 & 1.20 & 0.94 & 2.48 \\
\hline $3-6 \mathrm{~cm}$ & Euphorbia prostrata & 1 & 44 & 1 & 0.00 & 0.23 & 0.17 & 0.06 & 1.00 & 0.79 & 1.08 \\
\hline $3-6 \mathrm{~cm}$ & Ipomoea indica & 1 & 44 & 1 & 0.00 & 0.23 & 0.17 & 0.06 & 1.00 & 0.79 & 1.08 \\
\hline $3-6 \mathrm{~cm}$ & Ocimum urticifolium & 6 & 267 & 6 & 0.02 & 1.41 & 1.04 & 0.37 & 1.00 & 0.79 & 2.56 \\
\hline $3-6 \mathrm{~cm}$ & Parthenium hysterophorus & 58 & 2578 & 11 & 0.04 & 2.58 & 10.07 & 3.53 & 5.27 & 4.15 & 10.26 \\
\hline $3-6 \mathrm{~cm}$ & Physalis lagascae & 2 & 89 & 1 & 0.00 & 0.23 & 0.35 & 0.12 & 2.00 & 1.57 & 1.93 \\
\hline $3-6 \mathrm{~cm}$ & Trifolium simense & 3 & 133 & 2 & 0.01 & 0.47 & 0.52 & 0.18 & 1.50 & 1.18 & 1.83 \\
\hline
\end{tabular}


Table 12 Vertical soil seed bank composition, abundance, density, and IVI (Continued)

\begin{tabular}{|c|c|c|c|c|c|c|c|c|c|c|c|}
\hline Soil layer & Species & $\mathrm{Ab}$ & $\mathrm{SBD} / \mathrm{m}^{2}$ & $F$ & $\mathrm{AF}$ & $R_{1}$ & $A D$ & $R_{2}$ & Aab & $R_{3}$ & $I_{\mathrm{V} I}$ \\
\hline $6-9 \mathrm{~cm}$ & Amaranthus thunbergii & 11 & 489 & 4 & 0.02 & 0.94 & 1.91 & 0.67 & 2.75 & 2.17 & 3.77 \\
\hline $6-9 \mathrm{~cm}$ & Bidens pilosa & 4 & 178 & 4 & 0.02 & 0.94 & 0.69 & 0.24 & 1.00 & 0.79 & 1.97 \\
\hline $6-9 \mathrm{~cm}$ & Brachiaria leersioides & 55 & 2444 & 25 & 0.10 & 5.85 & 9.55 & 3.35 & 2.20 & 1.73 & 10.93 \\
\hline $6-9 \mathrm{~cm}$ & Cenchrus ciliaris & 2 & 89 & 1 & 0.00 & 0.23 & 0.35 & 0.12 & 2.00 & 1.57 & 1.93 \\
\hline $6-9 \mathrm{~cm}$ & Crotalaria pycnostachya & 2 & 89 & 2 & 0.01 & 0.47 & 0.35 & 0.12 & 1.00 & 0.79 & 1.38 \\
\hline $6-9 \mathrm{~cm}$ & Eragrostis aethiopica & 12 & 533 & 4 & 0.02 & 0.94 & 2.08 & 0.73 & 3.00 & 2.36 & 4.03 \\
\hline $6-9 \mathrm{~cm}$ & Ocimum spicatum & 6 & 267 & 3 & 0.01 & 0.70 & 1.04 & 0.37 & 2.00 & 1.57 & 2.64 \\
\hline $6-9 \mathrm{~cm}$ & Parthenium hysterophorus & 23 & 1022 & 8 & 0.03 & 1.87 & 3.99 & 1.40 & 2.88 & 2.26 & 5.54 \\
\hline $6-9 \mathrm{~cm}$ & Physalis lagascae & 3 & 133 & 2 & 0.01 & 0.47 & 0.52 & 0.18 & 1.50 & 1.18 & 1.83 \\
\hline $6-9 \mathrm{~cm}$ & Trifolium simense & 1 & 44 & 1 & 0.00 & 0.23 & 0.17 & 0.06 & 1.00 & 0.79 & 1.08 \\
\hline
\end{tabular}

Notice: $A b$ abundance per soil layer, $S B D$ soil seed bank density per $\mathrm{m}^{2}, F$ frequency, $A F$ absolute frequency, $R_{1}$ relative frequency, $A D$ absolute density, $R_{2}$ relative density, $A a b$ absolute abundance, $R_{3}$ relative abundance, $I_{V I}$ importance value index 
Table 13 Effects of physiographic factors on mean values of soil seed bank patterns

\begin{tabular}{|c|c|c|c|c|}
\hline Physiographic factors & & $H^{\prime}$ & $R$ & $E^{\prime}$ \\
\hline \multirow[t]{3}{*}{ Alt (m.a.s.l) } & $740-790$ & $1.37 \pm 0.04 a$ & $4.56 \pm 0.17 a$ & $0.96 \pm 0.01 a$ \\
\hline & $791-841$ & $1.36 \pm 0.04 a$ & $4.48 \pm 0.16 a b$ & $0.95 \pm 0.004 a$ \\
\hline & $>841$ & $1.20 \pm 0.02 b$ & $4.09 \pm 0.1 b$ & $0.91 \pm 0.001 b$ \\
\hline \multirow[t]{7}{*}{ Aspect (direction) } & North & $1.15 \pm 0.04 b$ & $3.81 \pm 0.17 d$ & $0.92 \pm 0.01 b c$ \\
\hline & Northeast & $1.09 \pm 0.03 b$ & $3.37 \pm 0.11 \mathrm{ed}$ & $0.96 \pm 0.005 \mathrm{ba}$ \\
\hline & Northwest & $1.59 \pm 0.00 \mathrm{a}$ & $7.00 \pm 0.00 \mathrm{a}$ & $0.82 \pm 0.00 \mathrm{e}$ \\
\hline & East & $1.52 \pm 0.04 a$ & $5.21 \pm 0.17 \mathrm{cb}$ & $0.96 \pm 0.006 \mathrm{ba}$ \\
\hline & West & $1.46 \pm 0.05 a$ & $4.54 \pm 0.17 c$ & $0.98 \pm 0.006 a$ \\
\hline & Southeast & $0.88 \pm 0.08 c$ & $2.91 \pm 0.32 \mathrm{e}$ & $0.88 \pm 0.01 \mathrm{dc}$ \\
\hline & Southwest & $1.07 \pm 0.08 b$ & $3.4 \pm 0.13 \mathrm{ed}$ & $0.87 \pm 0.04 d$ \\
\hline \multirow[t]{12}{*}{ Slope (degree) } & 0 & $1.31 \pm 0.04 \mathrm{bac}$ & $4.8 \pm 0.14 b$ & $0.85 \pm 0.02 \mathrm{de}$ \\
\hline & 0.1 & $0.69 \pm 0.00 f$ & $2.00 \pm 0.00 \mathrm{e}$ & $1.00 \pm 0.00 a$ \\
\hline & 0.2 & $1.12 \pm 0.08 \mathrm{edc}$ & $4.13 \pm .37 \mathrm{cbd}$ & $0.88 \pm 0.01 \mathrm{dc}$ \\
\hline & 0.3 & $1.39 \pm 0.00 \mathrm{bac}$ & $4.00 \pm 0.00 \mathrm{cbd}$ & $1.00 \pm 0.00 a$ \\
\hline & 0.5 & $1.59 \pm 0.00 \mathrm{a}$ & $7.0 \pm 0.00 \mathrm{a}$ & $0.82 \pm 0.00 \mathrm{fe}$ \\
\hline & 1 & $1.26 \pm 0.03 \mathrm{bdc}$ & $3.99 \pm 0.13 \mathrm{cbd}$ & $0.98 \pm 0.003 a$ \\
\hline & 1.5 & $1.31 \pm 0.11 \mathrm{bac}$ & $4.53 \pm .41 \mathrm{cb}$ & $0.91 \pm 0.06 \mathrm{bc}$ \\
\hline & 2 & $1.48 \pm 0.03 \mathrm{ba}$ & $4.91 \pm 0.13 b$ & $0.96 \pm 0.005 a$ \\
\hline & 2.5 & $1.11 \pm 0.096 \mathrm{edc}$ & $3.41 \pm 0.3 \mathrm{~cd}$ & $0.96 \pm 0.01 \mathrm{ba}$ \\
\hline & 3 & $0.94 \pm 0.06 \mathrm{ef}$ & $2.94 \pm 0.2 \mathrm{ed}$ & $0.91 \pm 0.01 c$ \\
\hline & 4 & $0.86 \pm 0.06 \mathrm{ef}$ & $3.0 \pm 0.00 \mathrm{ed}$ & $0.78 \pm 0.06 f$ \\
\hline & 6 & $1.0 \pm 0 \mathrm{ed}$ & $4.0 \pm 0.00 \mathrm{cbd}$ & $0.72 \pm 0.00 \mathrm{~g}$ \\
\hline \multicolumn{5}{|l|}{ Human activities } \\
\hline \multirow[t]{4}{*}{ Human impacts } & Nil & $1.32 \pm 0.04 a$ & $4.74 \pm 0.17 a$ & $0.92 \pm 0.01 b$ \\
\hline & Low & $1.29 \pm 0.04 \mathrm{ba}$ & $4.41 \pm 0.14 \mathrm{ba}$ & $0.91 \pm 0.01 b$ \\
\hline & Moderate & $1.196 \pm 0.03 b$ & $3.73 \pm 0.10 c$ & $0.95 \pm 0.01 a$ \\
\hline & Heavy & $1.28 \pm 0.05 \mathrm{ba}$ & $4.19 \pm 0.19 b$ & $0.95 \pm 0.01 a$ \\
\hline \multirow[t]{4}{*}{ Grazing intensity } & Nil & $1.37 \pm 0.04 \mathrm{ba}$ & $5.01 \pm 0.19 a$ & $0.93 \pm 0.01 b$ \\
\hline & Low & $1.43 \pm 0.02 \mathrm{a}$ & $4.74 \pm 0.10 a$ & $0.93 \pm 0.01 b$ \\
\hline & Moderate & $1.28 \pm 0.04 b$ & $4.07 \pm 0.13 b$ & $0.961988 a$ \\
\hline & Heavy & $1.034 \pm 0.03 c$ & $3.47 \pm 0.11 \mathrm{c}$ & $0.89 \pm 0.01 c$ \\
\hline \multirow[t]{4}{*}{ Disturbance intensity } & Nil & $1.36 \pm 0.05 \mathrm{ba}$ & $4.78 \pm 0.20 \mathrm{a}$ & $0.95 \pm 0.01 a$ \\
\hline & Low & $1.42 \pm 0.03 a$ & $4.85 \pm 0.16 a$ & $0.94 \pm 0.01 a$ \\
\hline & Moderate & $1.28 \pm 0.03 b$ & $4.15 \pm 0.11 b$ & $0.95 \pm 0.01 a$ \\
\hline & Heavy & $1.05 \pm 0.03 c$ & $3.52 \pm 0.11 \mathrm{c}$ & $0.89 \pm 0.01 b$ \\
\hline
\end{tabular}

Notice: $H^{\prime}$ is the Shannon-Wiener index, $R$ is species richness, $E^{\prime}$ is the Shannon evenness; the same letters indicate insignificant variations at $P<0.05$

\section{Acknowledgements}

The authors are thankful to Arba Minch and Addis Ababa Universities for financing the project. The first author special thanks Afar pastoral communities for their cooperation and assistance during data collection. Department of natural resources management in pastoral and agro-pastora districts of Amibara and Awash Fentale are highly acknowledged for material and human resources assistance during site selection and data collection. Finally, the authors also extend their gratitude to Central Ethiopian Environmental, Forestry, and Climate Change Research Center for their permission to use the greenhouse for soil seed separation.

\section{Authors' Contributions}

All authors have equally contributed the inputs for the manuscript. All authors read and approved the final manuscript
Funding

No funding applicable

Availability of data and materials

All data are available in the manuscript.

Ethics approval and consent to participate

All authors are participating to contribute for the manuscript improvement all aspects.

Consent for publication

All authors have an agreement to publish this manuscript.

Competing interests

All computing interests are shared by all authors. 


\section{Author details}

'Arba Minch University, College of Agricultural Sciences, Natural Resources Management, Arba Minch, Ethiopia. ${ }^{2}$ College of Natural Sciences, Plant Biology and Biodiversity Management, Addis Ababa University, P.O. Box 3434, Addis Ababa, Ethiopia. ${ }^{3}$ The World Agroforestry Centre (ICRAF), UN Avenue, P.O. Box 30677, Nairobi, Kenya.

\section{Received: 25 July 2019 Accepted: 10 October 2019}

\section{Published online: 19 December 2019}

\section{References}

Abebe $Y$ (2012). Ecological and economic dimensions of the paradoxical invasive species-Prosopis juliflora and policy challenges in Ethiopia, J Econ Sustainable Dev ISSN 2222-1700, 3(8), ISSN 2222-2855, www.iiste.org.

Abella SR, Chiquoine LP, Vanier CH (2013). Characterizing SBs and relationships to plant communities. Plant Ecology, 214 (5), Available at: https://www.jstor.org/ stable/23500356.

Arevalo-Sandi A, Bobrowiec PED, Rodriguez Chuma VJU, Norris D. Diversity of terrestrial mammal seed dispersers along a low land Amazon forest regrowth gradient. PLoS ONE. 2018;13(3):e0193752. https://doi.org/10.1371/journal. pone.0193752.

Argaw M, Teketay D, Olsson M (1999) Soil seed flora, germination and regeneration pattern of woody species in an Acacia woodland of the Rift Valley in Ethiopia. J Arid Environ 43: 411-435 Available online at http://www. idealibrary.com

Ayanu Y, Anke J, Detlef M. Ecosystem engineer unleashed: Prosopis juliflora threatening ecosystem services? Regional Environ Change. 2015;15:155-67. https://doi.org/10.1007/s10113-014-0616-x.

Bekele T. Plant population dynamics of Dodonaea angustifolia and Olea europaea spp. cuspidata in dry Afromontane Forests of Ethiopia, (Ph.D. Thesis). Acta Universitatis Upsaliensis, Uppsala, 2000;559.

Berhanu A, Tesfaye G. The Prosopis juliflora dilemma, impact on dryland biodiversity and some controlling methods. J Dry Lands. 2006; (2):158-64.

Bilal MA (2015). A review of endozoochorous seed dispersal by herbivores and its potential effects on seed germination. MSc Thesis, Norwegian University of Life Sciences, As, Norway https://brage.bibsys.no/xmlui/bitstream/ handle/11250/2384014/

Biswas SR, Malik AU. Disturbance effects on species diversity and functional diversity in riparian and upland plant communities. Ecology. 2010;91(1):2835.

Bruun HH, Poschlod P (2006). Why are small seeds dispersed through animal guts: large numbers or seed size per se? Oikos 113: 402-411.Publishing, Ltd.

Bueno A, Baruch Z. Soil seed bank and the effect of needle litter layer on seedling emergence in a tropical pine plantation. Rev. Biol. Trop. (Int. J. Trop. Biol). 2011;59(3):1071-9. https://doi.org/10.15517/rbt.v0i0.3379.

Central Statistical Agency (CSA) (2013). Population projection of Ethiopia for all regions at district Level, Addis Ababa, Ethiopia.

Chaideftou E, Thanos CA, Bergmeier E, Kallimanis A, Dimopoulos P. Seed bank composition and aboveground vegetation in response to grazing in subMediterranean oak forests (NW Greece). Plant Ecology. 2009;201:255-65. https://doi.org/10.1007/s11258-008-9548-1.

Chapman Jl, McEwan RW. The role of environmental filtering in structuring Appalachian Tree Communities: topographic influences on functional diversity are mediated through soil characteristics. Forests. 2018;9(19):1-16. https://doi.org/10.3390/f9010019.

Cheng ER, Jefferies RL, Carleton TJ. The relationship between vegetation and soil seed banks in an arctic coastal marsh. J Ecol. 2001;89:367-84.

Cox RD, Allen EB. The composition of soil seed banks in southern California coastal sage scrub and adjacent exotic grassland. Plant Ecol. 2007;198:37-46. https://doi.org/10.1007/s11258-007-9383-9.

Cox RD, Allen EB. The composition of soil seed banks in southern California coastal sage scrub and adjacent exotic grassland. Plant Ecol, 2008:198:37-46, https://doi.org/10.1007/s11258-007-9383-9.

da Luz GR, Mota GD, Spadeto C, Tolentino GS, Fernandes GW, Nunes YRF. Regenerative potential of the soil seed bank along an elevation gradient of rupestrian grassland in southeastern Brazil. Botany. 2017;96:281-98. https:// doi.org/10.1139/cjb-2017-0162.

Dalle G, Brigitte LM, Johannes I. Encroachment of woody plants and its impact on pastoral livestock production in the Borana lowlands, southern Oromia, Ethiopia, East African Wild Life Society. Afr J Ecol. 2006;44:237-46.
Dalling JW, Swaine MD, Garwood NC. Effect of soil depth on seedling emergence in tropical soil seed-bank investigations. Functional Ecol. 1995;9:119-21 http://www.jstor.org.

Dessalegn KT (2010). Assessment of rangeland degradation, its effect on soil seed bank flora and implications on carbon sequestration. A case study of Allaidege rangeland, Afar Region, Ethiopia, MSc Thesis, Haramaya University, pp22-139.

Dreber N. How best to quantify soil seed banks in arid rangelands of the Nama Karoo? Environ Monit Assess. 2011;173:813-824. https://doi.org/10.1007/ s10661-010-1425-4.

Duncan RP, Diez JM, Sullivan JJ, Wangen S, Miller AL. Safe sites, seed supply, and the recruitment function in plant populations. Ecology. 2009;90:2129-38.

Eager EA, Haridas CV, Pilson D, Rebarber R, Tenhumberg B. Disturbance frequency and vertical distribution of seeds affect long-term population dynamics: a mechanistic seed bank model. Am Naturalist. 2013;182(2). https://doi.org/10.1086/670987.

Egawa C, Tsuyuzaki S. The effects of litter accumulation through succession on seed bank formatiom for small- and large-seeded species. Journal of Vegetation Sciences. 2013;24:1062-1073. https://doi.org/10.1111/jvs.12037.

El-Keblawy A (2012). Impacts of Native and Exotic Prosopis Species on Native Plants in Aridlands of the UAE, International Conference on Ecology, Agriculture and Chemical Engineering (ICEACS'2012), Phuket, Thailand.

El-Keblawy A, Al-Rawai A. Impacts of the invasive exotic Prosopis juliflora (Sw.) D. C. on the native flora and soils of the UAE. Plant Ecology. 2007;190:23-35. https://doi.org/10.1007/s11258-006-9188-2.

Espinosa Cl, Luzuriaga AL, Cruz MD, Montero M, Escudero A. Co-occurring grazing and climate stressors have different effects on the total seed bank when compared to the persistent seed bank. J Vegetation Sci. 2013;24:1098107.

FAO (2006). Invasion of Prosopis juliflora in India, In Problems posed by the introduction of Prosopis species in selected countries, Italy Rome, p13.

Fengqin J, Tashpolat T, Nan W, Changyan T, Yuanming Z. Characteristics of soil seed banks at different geomorphic positions within the longitudinal dunes of the Gurbantunggut Desert, China. J Arid Land. 2017;9(3):355-67. https:// doi.org/10.1007/s40333-017-0055-x.

Friis I, Demissew S, Breugel PV. Atlas of potential vegetation of Ethiopia. Royal Danish Acad Sci Lett Biol Skrifter. 2010;58:1-315.

Gairola S, Sharma CM, Ghildiyal SK, Suyal S. Regeneration dynamics of dominant tree species along an altitudinal gradient in moist temperate valley slopes of the Garhwal Himalaya. Journal of Forestry Research. 2012;23(1):53-63. https:// doi.org/10.1007/s11676-012-0233-9.

Gautam MK, Kumar RM, Kumar AT. Patterns of diversity and regeneration in unmanaged moist deciduous forests in response to disturbance in Shiwalik Himalayas, India. J Asia-Pacific Biodivers. 2016;9:144-51.

Getachew S, Demissew S, Woldemariam T. Allelopathic effects of the invasive Prosopis juliflora (Sw.) DC on Selected Native Plant Species in Middle Awash, Southern Afar Rift of Ethiopia. Manag Biol Invasions. 2012;3(2):105-14. https:// doi.org/10.3391/mbi.2012.3.2.05.

Gioria M, Pysek P. The legacy of plant invasions: changes in the soil seed bank of invaded plant communities. Bioscience. 2016;66(1):40-53. https://doi.org/10. 1093/biosci/biv165.

Gonzalez SL, Ghermandi L. Comparison of methods to estimate soil seed banks: the role of seed size and mass. Commun Ecol. 2012;13(2):238-42.

Gul B, Ansari R, Flowers TJ, Khan AM. Germination strategies of halophyte seeds under salinity, Environmental and Experimental Botany; 2012. http://dx.DOI. org/10.1016/j.envexpbot.2012.11.006.

Haji J, Mohammed A. The economic impact of Prosopis juliflora on agropastoral households of Dire Dawa Administration, Ethiopia. Afr J Agric Res. 2013;8(9): 768-79. https://doi.org/10.5897/AJAR12.014.

Hadera G. A study on the ecology and management of the Dessa forest in the northeastern escarpment of Ethiopia. Unpublished MSc Thesis Addis Ababa University, 2000.

Hopfensperger N. A review of similarity between seed bank and standing vegetation across ecosystems. Oikos. 2007;1 16:1438-48. https://doi.org/10. $1111 / j .2007 .0030-1299.15818 . x$

IBM Corporation (1986, 2016). IBM SPSS Statistics 24 Core System User's Guide, USA printing.

Ilukor J, Rettberg S, Treydte A and Birner R (2016). To eradicate or not to eradicate? Recommendations on Prosopis juliflora management in Afar, Ethiopia, from an interdisciplinary perspective, Policy and Practice 6:14 https://doi.org/10.1186/s13570-016-0061-1 
Kaur R, Gonzales WL, Llambi LD, Soriano PJ, Callaway RM, Rout ME, Gallaher TJ, Inderjit. Community Impacts of Prosopis juliflora Invasion: Biogeographic and Congeneric Comparisons. PLoS ONE. 2012;7(9):e44966. https://doi.org/10. 1371/journal.pone.0044966.

Kebede AT. Sustaining the Allideghi Grassland of Ethiopia: Influence of Pastoralism and Vegetation Change, All Graduate Theses and Dissertations, Paper 309; 2009. http://digitalcommons.usu.edu/etd/309.

Kellerman MJS, Van Rooyen M. Seasonal variation in soil seed bank size andspecies composition of selected habitat types in Maputaland, South Africa. Bothalia. 2007;37(2):249-258.

Kent M, Coker P. Vegetation descriPJTion and analysis: A practical approach, England; 1992:97.

Koch MA, Scheriau C, Schupfner M, Bernhardt KG. Long term monitoring of the restoration and development of limestone grasslands in northwestern Germany: vegetation screening and soil seed bank analysis. Flora. 2011;206:52-65.

Kumar S, Mathur M. Impact of invasion by P. juliflora on plant communities in arid grazing lands, Tropical Ecology. 2014;55(1):33-46.

Li CD, Xiao B, Wang Q, Zheng R, Wu J (2017). Responses of SB and vegetation to the increasing intensity of human disturbance in a semi-arid region of Northern China. Sustainability, 9: 1837, https://doi.org/10.3390/su9101837.

Li Q, Fang H, Cai Q. Persistent soil seed banks along altitudinal gradients in the Qilian Mountains in China and their significance for conservation management. Af J Agric Res. 2011;6(10):2329-40. https://doi.org/10.5897/ AJAR10.1099.

Limenih M, Teketay D. Changes in soil seed bank composition and density following deforestation and subsequent cultivation of tropical dry Afromontane forest in Ethiopia. Journal of Tropical Ecology. 2006;47:1-12.

Lopez-Toledo L, Martínez-Ramos M. The soil seed bank in abandoned tropica pastures: the source of regeneration or invasion? Revista Mexicana de Biodiversidad. 2011;82:663-78.

Mack MC, D'Antonio CM. The effects of exotic grasses on litter decomposition in a Hawaiian Woodland: the importance of indirect effects. Ecosystems. 2003;6: 723-38. https://doi.org/10.1007/s10021-003-0119-y.

Madawala HMSP, Ekanayake SK, Perera GAD. Diversity, composition, and richness of soil seed banks in different forest communities at Dotalugala Man and Biosphere Reserve, Sri Lanka. Ceylon J Sci. 2016;45(1):43-55. https://doi.org/ 10.4038/cjs.v45i1.7363.

Magurran AE. Ecological diversity and its measurement. Cambridge: Cambridge University Press; 1988.

Mahdhi M, Tounekti T, Khemira H. The invasive character of Prosopis juliflora facilitated by its allelopathy and wide mutualistic interaction with soil microorganisms. J Biol Sci. 2018;18:115-23.

Maranon T. Soil seed bank and community dynamics in an annual-dominated Mediterranean salt-marsh. J Vegetation Sci. 1998;9:371-8.

Marcelo S, Mario G, Avi P, Jaime K. Effects of grazing on soil seed bank dynamics: an approach with functional groups. J Vegetation Sci. 2003;14:375-86.

Miranda RQ, Oliveira MTP, Correia RM, Almeida-Cortez JS, Pompelli MF. Germination of Prosopis juliflora (Sw) DC seeds after scarification treatments. Plant Species Biol. 2011;26:186-92.

Moles AT, Hodson DW, Webb CJ. Seed size and shape and persistence in the soil in the New Zealand flora. Oikos. 2000;89:541-5.

Mouissie AM, Lengkeek W, Van Diggelen R. Estimating adhesive seed-dispersal distances: field experiments and correlated random walks. Functional Ecol. 2005;19:478-86. https://doi.org/10.1111/j.1365-2435.2005.00992.x.

Muller-Dombis D, Ellenberg H. Aims and methods of vegetation ecology. New York: John Wiley and Sons; 1974.

Muturi GM, Poorter L, Mohren GMJ, Kigomo BN. Ecological impact of Prosopis species invasion in Turkwel riverine forest, Kenya. J Arid Environ. 2013;92:89-97.

Mworia JK, Kinyamario JI, Omari JK, Wambua JK. Patterns of seed dispersal and establishment of the invader Prosopis juliflora in the upper floodplain of Tana River, Kenya. Af J Range Forage Sci. 2011;28(1):35-41.

Olano JM, Caballero I, Escudero A (2012). Soil seed bank recovery occurs more rapidly than expected in semi-arid Mediterranean gypsum vegetation. Annals of Botany 109: 299-307Doi:https://doi.org/10.1093/aob/mcr260, available online at www.aob.oxfordjournals.org

Pasiecznik, NM, Felker P, Harris PJC, Harsh LN, Cruz G, Tewari JC, Cadoret K, Maldonado LJ (2001). The Prosopis juliflora - Prosopis pallida complex: a monograph, HDRA, Coventry, UK. pp172, ISBN: 0905343301.

Peco B, Traba J, Levassor C, Sanchez AM, Azcarate FM. (2003). Seed size, shape, and persistence in dry Mediterranean grass and scrublands. Seed Sci Res. 2003;13:87-95. https://doi.org/10.1079/SSR2002127.
Perera GA. Diversity and dynamics of the soil seed bank in tropical semideciduous forests of Srilanka, Tropical Ecology. 2005;46:65-78.

Qian J, Liu Z, Hatier JHB, Liu B. The vertical distribution of soil seed bank and its restoration implications in an active dune of Northeastern Inner Mongolia, China. Land Degradation Deve. 2016;27:305-15. https://doi.org/10.1002/ldr.2428.

Reubens B, Heyn M, Gebrehiwot K, Hermy M, Muys B. Persistent soil seed banks for natural rehabilitation of dry tropical forests in Northern Ethiopia. Tropicultura. 2007;25(4):204-14.

Robert DC, Edith BA. Composition of soil seed banks in southern California coastal sage scrub and adjacent exotic grassland. Plant Ecol. 2008;198:37-46. https://doi.org/10.1007/s11258-007-9383-9.

Rotich TI. Progressive effects of Prosopis juliflora (S.W.) (DC) on grazing natural pasture and browse plants in Baringo County, Kenya. Kenya: Unpublished MSc Thesis, University of Nairobi; 2016.

Saatkamp A, Pochlod P Lawrence, Venable D. (2014). The functional role of soil seed bank in natural communities. CABI. Seeds: The Ecology of Regeneration in Plant Communities, 3rd Edition (ed. Gallagher, R.S.).

Salazar A (2010). "Seed dynamics and seedling establishment of woody species in the tropical savannas of Central Brazil (Cerrado)". Open Access Dissertations pp. 371. https://scholarlyrepository.miami.edu/oa_dissertations/371

Sanou L, Zida D, Savadogo P, Thiombiano A (2018). Comparison of aboveground vegetation and soil seed bank composition at sites of different grazing intensity around a savanna woodland watering point in West Africa. Journal of Plant Research https://doi.org/10.1007/s10265-018-1048-3

SAS (2002). SAS/STAT user's guide, version 9.0, Cary, NC: SAS Institute.

Savadogo P, Sanou L, Dayambam SD, Bognounou F, Thiombiano A. Relationships between soil seed banks and aboveground vegetation along a disturbance gradient in the W National Park trans-boundary biosphere reserve, West Africa. J Plant Ecol. 2016;10(2):349-63. https://doi.org/10.1093/jpe/rtw025.

Shaheen H, Mashwani ZUR, Dar MEUI. Spatial patterns and diversity of alpine vegetation across Langer- Shandur Valley, Hindukush Himalayas. Curr. Sci. 2015;108(8):1534-9.

Shannon CE, Weaver W. The mathematical theory of communication. Urbana: University of Illinois Press; 1949.

Shiferaw H, Teketay D, Nemomissa S. Some biological characteristics that foster the invasion of Prosopis juliflora (Sw.) DC in Middle Awash Rift Valley Area, North-Eastern Ethiopia. J Arid Environ. 2004;58:135-54 www.elsevier.com.

Shiferaw W, Demissew S, Bekele T. Invasive alien plant species in Ethiopia: ecological impacts on biodiversity a review paper. Int J Mol Biol. 2018a;3(4): 171-8. https://doi.org/10.15406/ijmboa.2018.03.00072.

Shiferaw W, Demissew S, Bekele T. "Ecology of soil seed banks: implications for conservation and restoration of natural vegetation": a review. Int J Biodiversity Conservation. 2018b;10(10):380-93.

Sileshi D, Abraha B (2014). Assessment of soil seed bank composition of woody species in Hgumbirda National Forest Priority Area, Northeastern Ethiopia, Momona Ethiopian Journal of Science (MEJS), 6(1), pp25-44,2014 Mekelle University, ISSN:2220-184X.

Singh G, Rathod TR, Mutha S, Upadhyaya S, Bala N. Impact of Different Tree Species Canopy on Diversity and Productivity of Understory Vegetation in Indian Desert. Tropical Ecology. 2008;49(1):13-23.

Song G, Li X, Hui R (2017) Effect of biological soil crusts on seed germination and growth of an exotic and two native plant species in an arid ecosystem. PLoS ONE, 12(10). Available at: https://doi.org/10.1371/journal.pone.0185839

Sorensen T. A method of establishing groups of equal amplitude in plant sociology based on similarity of species content. Kongelige Danske Videnskabernes Selskab. Biologiske Skrifter. 1948;4:1-34.

Tekle K, Backus I, Skuglund J, Woldu Z. Vegetation on hill slopes of Wello, Ethiopia: degradation and regeneration. Nord Journal of Botany. 1997;17(5): 483-493.

Tesfaye G, Teketay D, Assefa Y, Fetena M. The impact of fire on the soil seed bank regeneration of Harena forest, southeast Ethiopia. Mountain Res Dev. 2004:24:354-61.

The R Core Team (2018). R: a language and environment for statistical computing. In: R Foundation for Statistical Computing (1999-2002), Version 3. 5.1 (2018-07-02).

Tiebel K, Huth F, Wagner S. Soil seed banks of pioneer tree species in European temperate forests: a review. iForest 11: 48-5. 2018. https://doi.org/10.3832/ ifor2400-011.

Tsegaye D, Moe RS, Vedeldc P, Aynekulu E. Land-use/cover dynamics in Northern Afar rangelands, Ethiopia. Agriculture, Ecosystems and Environment, 2010; 139:174-180. https://doi.org/10.1016/j.agee.2010.07.017. 
Valko O, Torok P, Tothmeresz B, Matus G. Restoration potential in seed banks of acidic fen and dry-mesophilic meadows: can restoration be based on local seed banks? Restoration Ecol. 2011;19:9-15.

Valko O, Tothmeresz B, Kelemen A, Simon E, Miglecz T, Lukacsc BA, Torok P. Environmental factors driving seed bank diversity in alkali grasslands. Agric Ecosystems Environ. 2014;182:80-7 https://doi.org/10.1016/j.agee.2013.06.012.

Wakie T, Paul HE, Jarnevich SC, Laituri M. Mapping current and potential distribution of non-native Prosopis juliflora in the Afar Region of Ethiopia. Plos One. 2014;9(11):e112854 www.plosone.org.

Woldu Z, Feoli E, Nigatu L. Partitioning an Elevation Gradient of Vegetation from Southeastern Ethiopia by Probabilistic Methods. Vegetation. 1989;81:189-198.

Woldu Z, Backeus I. The Shrubland Vegetation in Western Shewa, Ethiopia and Its Possible Recovery. Journal of Vegetation Science. 1991;2:173-180

Wootton JT. Effects of disturbance on species diversity: a multi-trophic perspective. American Naturalist. 1998;152(6):803-25.

Yirdaw E, Starr M, Negash M, Yimer F. Influence of topographic aspect on floristic diversity, structure and treeline of afromontane cloud forests in the Bale Mountains, Ethiopia. J. For. Res. 2015;26(4):919-931. https://doi.org/10.1007/ s11676-015-0155-4.

Zhang C, Dong Q, Chu H, Shi J, Li S, Wang Y, Yang X. Grassland community composition response to grazing intensity under different grazing regimes, Rangeland Ecology \& Management; 2017. https://doi.org/10.1016/j.rama.2017. 09.007.

Zobel M, Kalamees R, Püssa K, Roosaluste E, Moora M. Soil seed bank and vegetation in mixed coniferous forest stands with different disturbance regimes. Forest Ecol Manag. 2007;250:71-6.

\section{Publisher's Note}

Springer Nature remains neutral with regard to jurisdictional claims in published maps and institutional affiliations.

Ready to submit your research? Choose BMC and benefit from:

- fast, convenient online submission

- thorough peer review by experienced researchers in your field

- rapid publication on acceptance

- support for research data, including large and complex data types

- gold Open Access which fosters wider collaboration and increased citations

- maximum visibility for your research: over $100 \mathrm{M}$ website views per year

At $\mathrm{BMC}$, research is always in progress.

Learn more biomedcentral.com/submissions 